\title{
AVALIAÇÃO DO IOGURTE NATURAL PRODUZIDO COM LEITE DE BÚFALA CONTENDO DIFERENTES NÍVEIS DE GORDURA
}

\section{OTAVIANO CARNEIRO DA CUNHA NETO}

Dissertação de Mestrado apresentada à Comissão de Pós-Graduação da Faculdade de Zootecnia e Engenharia de Alimentos da USP, como parte dos requisitos para a obtenção do Título de Mestre em Zootecnia, na área de Concentração: Qualidade e Produtividade Animal.

Orientador: Prof. Dr. Carlos Augusto Fernandes de Oliveira 


\section{AVALIAÇÃO DO IOGURTE NATURAL PRODUZIDO COM LEITE DE BÚFALA CONTENDO DIFERENTES NÍVEIS DE GORDURA}

\section{OTAVIANO CARNEIRO DA CUNHA NETO}

Dissertação de Mestrado apresentada à Comissão de Pós-Graduação da Faculdade de Zootecnia e Engenharia de Alimentos da USP, como parte dos requisitos para a obtenção do Título de Mestre em Zootecnia, na área de Concentração: Qualidade e Produtividade Animal.

Orientador: Prof. Dr. Carlos Augusto Fernandes de Oliveira 


\section{FICHA CATALOGRÁFICA}

preparada pela

Biblioteca da Faculdade de Zootecnia e Engenharia de Alimentos da Universidade de São Paulo

Cunha Neto, Otaviano Carneiro da.

C972a Avaliação do iogurte natural produzido com leite de búfala contendo diferentes níveis de gordura / Otaviano Carneiro da Cunha Neto. -- Pirassununga, 2003.

$71 \mathrm{p}$.

Dissertação (Mestrado) -- Faculdade de Zootecnia e

Engenharia de Alimentos, Universidade de São Paulo, 2003. Departamento de Zootecnia.

Área de concentração: Qualidade e Produtividade Animal.

Orientador: Prof. Dr. Carlos Augusto Fernandes de Oliveira.

Unitermos: 1. Análise sensorial, leite 2. Análises físicoquímicas, leite 3. Iogurte 4. Leite, búfalo I. Título. 


\section{DEDICATÓRIA}

A distância não permite que a tenha próxima, que possa conviver com você ou mesmo acompanhar seu crescimento, mas saiba que em nenhum momento deixei de pensar em você. A você,

minha filha, que eu amo muito.

A minha mãe, que dedicou os melhores anos de sua vida aos seus filhos.

Aos meus irmãos, que sempre acreditaram em mim.

Ao meu avô, Manuel Santino da Silva.

- A vocês dedico este trabalho - 


\section{AGRADECIMENTOS}

Primeiramente Agradeço a Deus, pelo dom da vida. Sem ela nada seria possível.

À Coordenadoria de Aperfeiçoamento de Pessoal de Nível Superior - CAPES pela bolsa de estudo nos últimos meses de mestrado.

À Faculdade de Zootecnia e Engenharia de Alimentos da Universidade de São Paulo - Campus de Pirassununga e a todos os professores pelos ensinamentos doados e pela oportunidade para a realização deste curso.

Ao Prof. Dr. Carlos Augusto Fernandes de Oliveira pela orientação e amizade.

Ao Prof. Dr. Paulo José do Amaral Sobral pela orientação.

A Biblioteca da FZEA e seus funcionários, pelo auxílio sempre que necessário.

Aos Funcionários do Departamento de Zootecnia (ZAZ), Érica, Roseli, Rosilda, Rafael, enfim, a todos pelo auxílio durante o experimento e pelos bons momentos de descontração.

Aos Funcionários da Seção de pós-graduação da FZEA, Conceição, Clélia, Gláucia, Régis e Wagner.

Aos Amigos e amigas de Moradia e Pós-Graduação, Amaury Camilo Valinote, Eder Pinatti, Frederico (rinite), Gustavo Del Claro, Luís Roma Júnior, Maurício (Mau), Ricardo Muta Hotta, Weber Villas Boas Soares, Andrezza Maria Fernandes, Denise Ablas, Käthery, Paula Butkeraitis, Rosane Rubstein, Tatiana, pelos momentos agradáveis que passamos.

A Leila de Genova Gaya pela amizade, compreensão e paciência.

Aos Funcionários do Departamento de Nutrição e Produção Animal (VNP), José Garcia Franchini e Júnior, Lucinéia Mestieri, pela amizade e auxílio durante a minha breve permanência.

Fica aqui meus agradecimentos a todos que direta ou indiretamente colaboraram para que essa Dissertação se tornasse uma realidade. 


\section{SUMÁRIO}

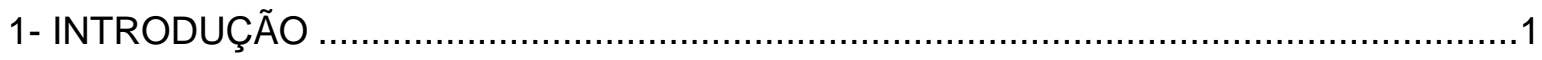

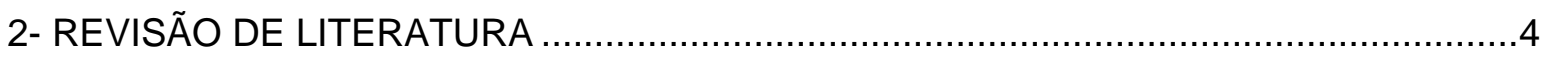

2.1- CARACTERÍSTICAS FíSICO-QUÍMICAS Do LEITE DE BÚFALA .........................................

2.2- CARACTERÍSTICAS MICROBIOLÓGICAS DO LEITE DE BÚFALA .....................................

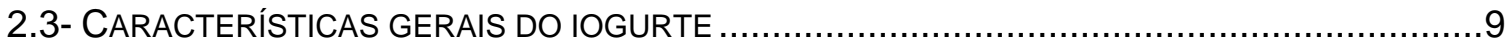

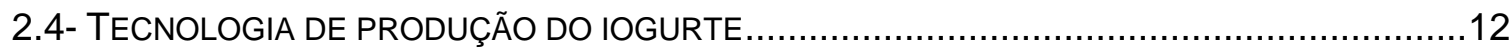

2.5- PARÂMETROS DE QUALIDADE DO IOGURTE .....................................................

2.5.1- Parâmetros microbiológicos ..................................................................... 16

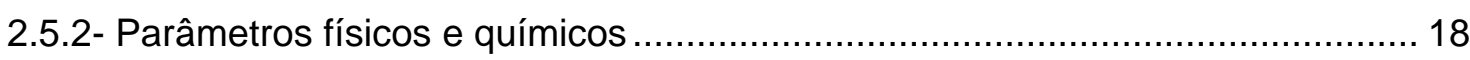

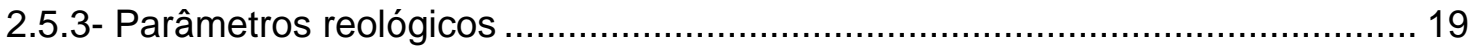

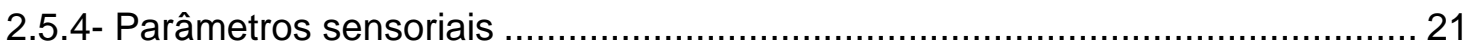

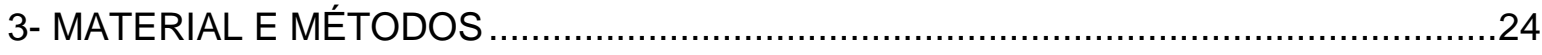

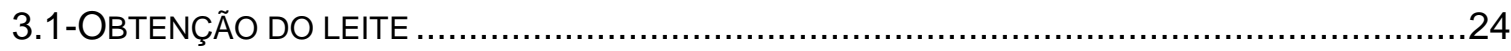

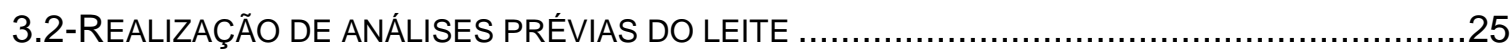

3.3- DESNATAMENTO E PADRONIZAÇÃO DO TEOR DE GORDURA ..........................................26

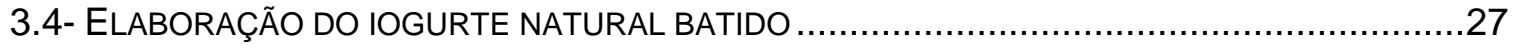

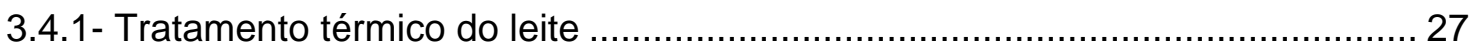

3.4.2- Semeadura, incubação e embalagem ........................................................ 28

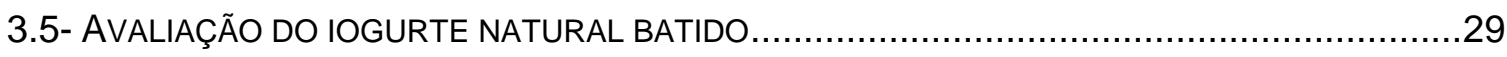

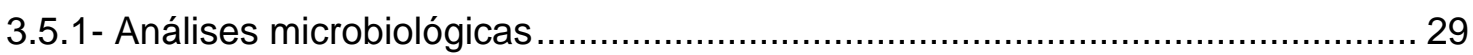

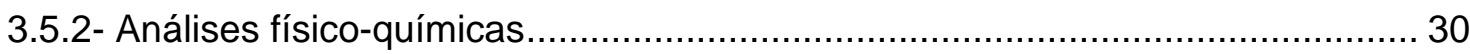

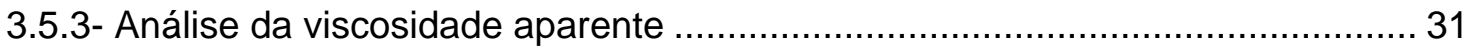

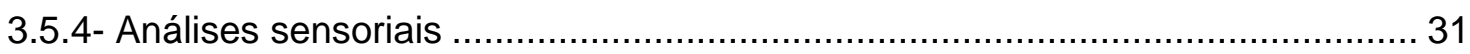

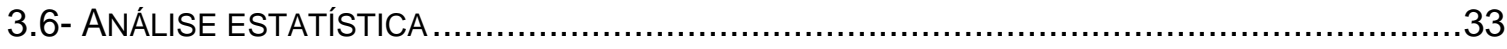

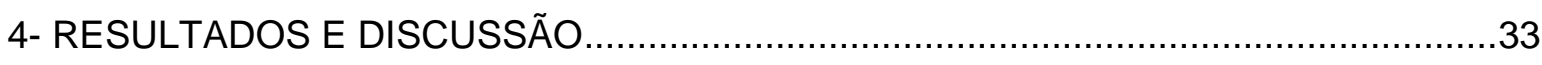




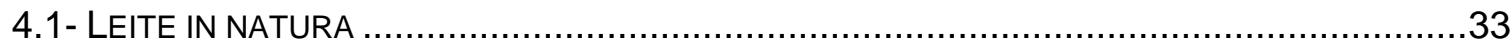

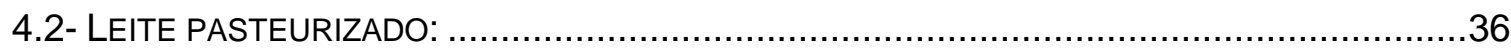

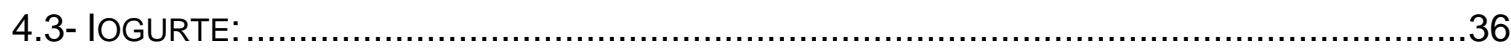

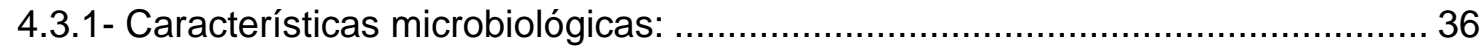

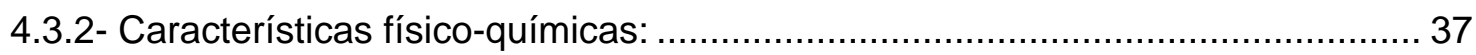

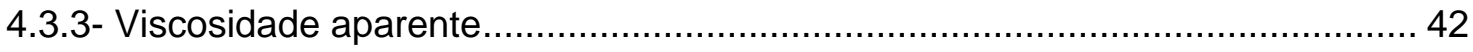

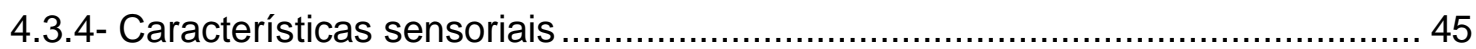

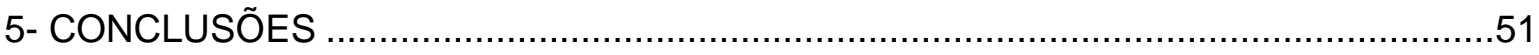

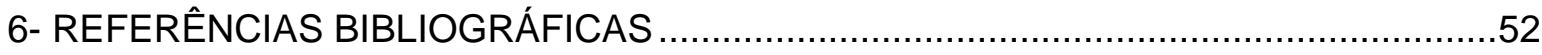




\section{LISTA DE FIGURAS}

Figura 1. Evolução dos níveis (Log UFC/ml) de microrganismos mesófilos e psicrotróficos no leite de búfala cru, previamente ao início do experimento.... 25

Figura 2. Desnatadeira utilizada para a separação do creme do leite de búfala. 27

Figura 3. Aspecto do iogurte de leite desnatado de búfala (Tratamento C) após agitação do coágulo

Figura 4. Fluxograma e resumo das atividades realizadas no experimento. 32

Figura 5. Evolução da acidez (expressa em \% de ácido lático/100 g do produto) e do $\mathrm{pH}$ dos iogurtes nos dias $1^{\circ}, 15^{\circ}$ e $30^{\circ}$ após a fabricação, de acordo com o tipo de tratamento utilizado.

Figura 6. Evolução do teor de gordura (\%), dos iogurtes nos dias $1^{\circ}, 15^{\circ}$ e $30^{\circ}$ após a fabricação, de acordo com o tipo de leite utilizado em cada tratamento.

Figura 7. Evolução do teor de proteína (\%), dos iogurtes nos dias $1^{\circ}, 15^{\circ}$ e $30^{\circ}$ após a fabricação, de acordo com o tipo de leite utilizado em cada tratamento.

Figura 8. Evolução do EST (\%), dos iogurtes nos dias $1^{\circ}, 15^{\circ}$ e $30^{\circ}$ após a fabricação, de acordo com o tipo de leite utilizado em cada tratamento.

Figura 9. Evolução do ESD (\%), dos iogurtes nos dias $1^{\circ}, 15^{\circ}$ e $30^{\circ}$ após a fabricação, de acordo com o tipo de leite utilizado em cada tratamento.

Figura 10. Viscosidade aparente (média, $n=5$ ) do iogurte no $1^{\circ}$ dia de armazenamento.

Figura 11. Viscosidade aparente (média, $\mathrm{n}=5$ ) do iogurte no $15^{\circ}$ dia de armazenamento.

Figura 12. Viscosidade aparente (média, $\mathrm{n}=5$ ) do iogurte no $30^{\circ}$ dia de armazenamento.

Figura 13. Evolução da nota média atribuída ao aspecto do iogurte durante 30 dias de armazenamento. 
Figura 14. Evolução da nota média atribuída à consistência do iogurte durante 30 dias de armazenamento.

Figura 15. Evolução da nota média atribuída ao odor do iogurte durante 30 dias de armazenamento. 48

Figura 16. Evolução da nota média atribuída ao sabor do iogurte durante 30 dias de armazenamento. 49

Figura 17. Evolução da nota final de avaliação sensorial do iogurte durante 30 dias de armazenamento. 


\section{LISTA DE TABELAS}

Tabela 1. Parâmetros físico-químicos e microbiológicos do leite de búfala integral in natura.

Tabela 2. Parâmetros microbiológicos do leite de búfala pasteurizado, de acordo com os tratamentos utilizados na fabricação do iogurte.

Tabela 3. Parâmetros microbiológicos do iogurte no $1^{\circ}$ dia após a fabricação, de acordo com os tratamentos utilizados na fabricação do iogurte.

Tabela 4. Parâmetros físico-químicos do iogurte nos dias $1^{\circ}, 15^{\circ}$ e $30^{\circ}$ após a fabricação, de acordo com os tratamentos utilizados na fabricação do iogurte.

Tabela 5. Viscosidade aparente do iogurte nos dias $1^{\circ}, 15^{\circ}$ e $30^{\circ}$ após a fabricação, de acordo com os tratamentos utilizados na fabricação do iogurte.

Tabela 6. Notas da análise sensorial do iogurte nos dias $1^{\circ}, 15^{\circ}$ e $30^{\circ}$ após a fabricação, de acordo com os tratamentos utilizados na fabricação do iogurte. 


\section{LISTA DE ABREVIATURAS, SÍMBOLOS E SIGLAS}

$\begin{array}{ll}\text { CCS } & \text { Contagem de células somáticas } \\ \text { CP } & \text { Centipoise } \\ { }^{\circ D} & \text { Graus Dornic } \\ \text { ESD } & \text { Extrato seco desengordurado } \\ \text { EST } & \text { Extrato seco total } \\ \text { IC } & \text { Índice crioscópico } \\ \text { Log } & \text { Logarítmo } \\ \text { UFC/mL } & \text { Unidade formadora de colônia por mililitro } \\ \mu \mathrm{m} & \text { micrômetro } \\ \mathrm{NMP} / \mathrm{mL} & \text { Número mais provável por mililitro } \\ \mathrm{CBT} & \text { Contagem bacteriana total } \\ \mathrm{rpm} & \text { Rotações por minuto } \\ \text { PCA } & \text { Plate count agar (Agar padrão para contagem) } \\ \text { VBBL } & \text { Verde bile brilhante lactose }\end{array}$




\section{RESUMO}

O iogurte é considerado um importante derivado lácteo para a alimentação humana. No Brasil, este produto é elaborado tradicionalmente a partir do leite bovino. A produção de iogurte, porém, constitui uma excelente alternativa para o aproveitamento do leite de búfala, embora possam ocorrer problemas na aceitação do produto devido ao elevado teor de gordura no leite original. O presente trabalho teve por objetivo avaliar a estabilidade e algumas características de qualidade do iogurte natural elaborado a partir do leite de búfala contendo diferentes níveis de gordura. Para isto, o leite foi desnatado até atingir $0,5 \%$ de gordura e misturado a volumes convenientes de leite integral, com a finalidade de obter os seguintes tratamentos: A - teor de iogurte integral, B - iogurte padronizOado, contendo 3,0\% de gordura e C - iogurte desnatado, contendo $0,5 \%$ de gordura. Os leites foram utilizados separadamente para a fabricação do iogurte natural batido, o qual foi embalado em frascos de polietileno de 1 $\mathrm{L}$ e estocado câmara fria a $5^{\circ} \mathrm{C}$ por 30 dias. Amostras de iogurte foram coletadas nos dias 1, 15 e 30, após a fabricação, com vistas à realização das seguintes análises: contagem de coliformes, mesófilos e psicrotróficos; determinação do pH, acidez titulável, gordura, proteína e matéria seca; viscosidade aparente e análise sensorial, realizada através de painel não treinado. Os resultados foram analisados através de ANOVA. Os dados obtidos nas análises microbiológicas não apresentaram diferenças significantes $(P>0,05)$ entre os iogurtes produzidos com leite bubalino integral, padronizado e desnatado. Não foram observadas variações importantes nas características físico-químicas estudadas nos diferentes tipos de iogurte, durante o período de 30 dias de estocagem. A viscosidade também não foi influenciada $(P>$ $0,05)$ pelos níveis de gordura nas análises dos dias 1, 15 e 30, indicando que a adição de leite em pó não é necessária para padronizar o teor de sólidos totais no iogurte produzido a partir de leite bubalino desnatado. Comparado ao iogurte desnatado, o iogurte produzido com leite padronizado apresentou notas significativamente maiores $(P<0,05)$ na análise sensorial nos dias 15 e 30. Conclui-se que todos os tipos de iogurte apresentaram características aceitáveis sob os aspectos microbiológico e físico-químico, embora o iogurte produzido com leite bubalino contendo 3,0\% de gordura tenha demonstrado uma melhor qualidade sensorial, bem como uma boa estabilidade durante o armazenamento. 


\begin{abstract}
Yoghurt is considered an important dairy product for human nutrition. In Brazil, it is traditionally manufactured from cow's milk. Yoghurt can be also an excellent alternative for utilization of buffalo milk. However, consumers may have some acceptance problems in relation to buffalo yoghurt because of the original milk high fat content. The aim of the present study was to evaluate some characteristics and the stability of yoghurt produced with buffalo milk standardised at different fat levels. The milk was defatted down up $0.5 \%$ and mixed with adequate volumes of whole milk, resulting in three treatments: A- whole yoghurt, B- standard yoghurt with $3.0 \%$ fat content, and Cskim yoghurt with $0.5 \%$ fat content. Standardised milks were used separately for manufacture of stirred whole plain yoghurt. Yoghurts were stored in 1-L polyethylene bottles at $5^{\circ} \mathrm{C}$ for 30 days. Samples were collected at 1,15 and 30 days of storage and submitted to the following analysis: coliform, mesophile and psychrotrophic counts, determination of $\mathrm{pH}$, fat and protein content, total solids and non-fat solids, viscosity and sensorial evaluation. Results were analysed using one-way ANOVA. No significant differences were observed among of treatments on microbiological $(P>0.05)$ after evaluation. No important variations in chemical parameters were observed during 30 days storage of all yoghurts. Viscosity was not influenced $(P>0.05)$ by fat content in yoghurts on days 1, 15 and 30 after manufacture, hence indicating that addition of milk powder is not necessary to standardise solid contents in yoghurt made from defatted buffalo milk. Standardised yoghurt obtained significantly $(P<0.05)$ higher grades in sensorial analysis at 15 and 30 days storage when compared to yoghurt produced from skim milk. It was concluded that all yoghurts present acceptable microbiological, physical and chemical characteristics. However, the product made from buffalo milk containing 3.0\% fat showed better sensorial quality and good stability during storage.
\end{abstract}




\section{1- INTRODUÇÃO}

O búfalo (Bubalus bubalis) é uma espécie originária da Ásia, que se difundiu para praticamente todos os continentes. Em 1998, o contingente mundial foi estimado em cerca de 164,3 milhões de animais, tendo ocorrido um acréscimo no número de cabeças de 53\% no período compreendido entre os anos de 1970 e 1998 (FAO, 1999). Nas Américas, o principal contingente encontra-se no Brasil, com um rebanho que saltou de 890 mil cabeças em 1993 para aproximadamente 1,2 milhões de cabeças em 2002 (Anualpec, 2002). A bubalinocultura leiteira vem se destacando em diversas regiões do país, particularmente nas regiões Sul e Sudeste, além das regiões Norte e Nordeste. São encontradas quatro raças oficialmente reconhecidas de búfalo doméstico: Jafarabadi (de dupla aptidão, com concentração no Sul do país e nos estados de São Paulo e Minas Gerais), Murrah (mais eficiente na produção de leite e manteiga, concentrando-se no Sul do país e estados de São Paulo e Minas Gerais), Mediterrâneo (com característica de animal de dupla aptidão, todavia, com tendência leiteira, predominante na região Nordeste do Brasil) e Carabao, que raramente é usada para a produção de leite.

A elevada rusticidade dos búfalos, associada à docilidade e à facilidade de adaptação em condições geográficas adversas, como áreas alagadiças, tem contribuído para estimular a criação destes animais, principalmente em locais de difícil desenvolvimento da pecuária bovina e da agricultura. Os búfalos são tradicionalmente considerados como animais de tração e produtores de carne, porém, com a escolha de animais selecionados e a obtenção de melhores níveis de desempenho dos rebanhos, os produtores têm demonstrado um crescente interesse pela produção leiteira, com vistas, sobretudo, ao fornecimento de leite para elaboração de derivados.

Sabe-se ainda que, quando comparado com o leite de outras espécies de mamíferos, o leite de búfala apresenta valores elevados de seus constituintes físicoquímicos. Assim, vários estudos têm sido desenvolvidos para determinar as 
propriedades físico-químicas e os valores nutricionais do leite e derivados, visando sua utilização plena na alimentação humana (Vieira \& Neves, 1980; Verruma \& Salgado, 1994; Nader Filho et al., 1996; Queiroz et al., 2002).

Para a utilização do leite desta espécie na alimentação humana, entretanto, é necessário que o mesmo tenha uma boa condição higiênico-sanitária em todas as etapas da produção, a fim de evitar a presença de microrganismos patogênicos ou deteriorantes nos produtos destinados ao consumo. Também é importante que as características físico-químicas e sensoriais sejam analisadas nos produtos lácteos, uma vez que são influenciadas pela qualidade do leite utilizado como matéria-prima.

O leite bubalino é utilizado para elaborar diferentes derivados lácteos, dentre eles podem ser citados os diversos tipos de queijos, iogurtes e outros leites fermentados. As características destes derivados são variáveis conforme a região de origem, as quais foram ajustadas de acordo com as preferências locais em vários países. Com isso, a utilização do leite bubalino na produção de leites fermentados, adicionado ou não de leite bovino, tornou possível o desenvolvimento de diversos tipos de produtos, tais como dahi, khoa, kúselo mleko, mozzrella, surati, cheddar, abady (Ganguli, 1979; Ferrara \& Intrieri, 1975).

No Brasil, o aperfeiçoamento do parque tecnológico e a abertura do mercado interno possibilitaram uma maior participação dos laticínios no faturamento da indústria de alimentos, de 10\% para 18,6\% (Fonseca \& Morais, 1999). Com isso, houve um aumento na atividade de produção de iogurtes nos últimos anos, a qual saltou de aproximadamente 60 mil toneladas em 1980, para 470 mil toneladas em 1998. O consumo interno deste produto também aumentou, principalmente no período de 1994 a 1997, quando variou de 1,4 para 3,0 kg/habitante/ano (Anuário Milkbizz, 1999).

Os dados apresentados são referentes ao iogurte produzido com leite bovino. Não existem estatísticas de produção e consumo de iogurtes de leite de búfala, exclusivamente, apesar deste produto constituir uma excelente alternativa para 
a destinação do leite bubalino produzido em nossas condições. Assim, deve-se ressaltar a importância de estudos que avaliem os processos tecnológicos mais adequados para a elaboração do iogurte produzido com leite desta espécie.

Com base nos aspectos mencionados, e considerando que existem poucos dados disponíveis na literatura sobre a caracterização do iogurte produzido exclusivamente com leite de búfala, constituíram objetivos do presente trabalho:

a) Determinar parâmetros microbiológicos (contagens de mesófilos, psicrotróficos e Número Mais Provável [NMP] de coliformes a $35^{\circ} \mathrm{C}$ e $\left.45^{\circ} \mathrm{C}\right)$, físico-químicos $(\mathrm{pH}$, acidez, percentuais de gordura, proteína, extrato seco total [EST] e desengordurado [ESD]), reológicos (viscosidade aparente) e sensoriais do iogurte natural batido, produzido com leite bubalino contendo diferentes níveis de gordura (teor de gordura integral, padronizado a 3,0\% e leite desnatado a 0,5\% de gordura);

b) Avaliar a estabilidade dos produtos elaborados ao longo de 30 dias após a fabricação. 


\section{2- REVISÃO DE LITERATURA}

\section{1- Características Físico-Químicas do Leite de Búfala}

O leite bubalino é utilizado para a elaboração de diferentes derivados lácteos. Os produtos variam de acordo coma região e hábitos culturais onde este é produzido. No Brasil, são elaborados desde o tradicional queijo mozzarella Italiano, o CPATU branco macio e o queijo Marajoara, doce de leite pastoso ou em tabletes, manteiga e iogurte tradicional (Hühn et al., 1991; Queiroz et al., 2003). Ainda produz-se a mozzarelline (Uova di búfala), o queijo provolone, o queijo vittoria, uma ricota gorda (ricotta in salvieta), queijo azul, queijo tipo mascarpone e, ainda, os queijos cheddar e surati (Ferrara \& Intrieri, 1975; Ganguli, 1979; Furtado, 1980b; Van Dender et al., 1988).

As características de composição e as propriedades físico-químicas do leite bubalino podem apresentar muitas variações devido a vários fatores, como o estágio de lactação e a estação do ano (Dubey et al., 1997). Observam-se, também, variações acentuadas conforme a raça, a produção individual das búfalas, a alimentação e o número de ordenhas por dia, entre outras causas (Akbar et al., 1999).

A densidade do leite de búfala pode variar de acordo com os diferentes meses do período de lactação, alcançando níveis entre 1,031 a 1,034g/mL (Furtado, 1980). Nader Filho et al. (1996) e Neves (1985), no entanto, observaram valores médios um pouco superiores, da ordem de 1,0325 e 1,0347 g/mL respectivamente.

Os valores de pH podem variar de 6,41 (Furtado, 1980a) a 6,97 (Nader Filho et al. 1996). Segundo Nader Filho et al. (1996) os valores de pH variam de acordo com os diferentes meses de lactação.

Os trabalhos encontrados na literatura brasileira demonstram que a acidez do leite de búfala pode oscilar entre $20^{\circ} \mathrm{D}$ (Nader Filho et al., 1983) e 22,3 D (Nader Filho et al., 1986). A título de comparação, a acidez encontrada para o leite bovino pode atingir valores de 14 a $20^{\circ} \mathrm{D}$ (Nader Filho et al., 1986). É importante ressaltar que a 
acidez titulável é decorrente tanto da presença do ácido lático como de outros compostos, principalmente do teor de proteína (caseína), o qual é maior no leite bubalino (Furtado,1980b). As proteínas do leite possuem caráter anfótero, podendo reagir tanto com bases como com ácidos. Assim, o leite bubalino possui efeito tamponante quando é submetido à titulação, sendo que o teor de proteínas totais aumenta significativamente sua acidez titulável, sem influência aparente na acidez real (Furtado, 1980a).

O índice crioscópico (IC) determina o ponto de congelamento do leite, sendo utilizado pela indústria para verificar com exatidão se houve ou não fraude por adição de água no leite. Segundo Nader Filho et al. (1983) e Antunes et al. (1988), o IC do leite de búfala poderá oscilar entre $-0,531$ e $-0,548{ }^{\circ} \mathrm{C}$, respectivamente, com algumas variações durante os diferentes meses do período de lactação (Nader Filho et al., 1996). Comparativamente, o IC do leite bovino pode variar de $-0,530$ a $-0,550{ }^{\circ} \mathrm{C}$ (Brasil, 1981).

O EST do leite bubalino é importante para a obtenção de iogurtes com uma melhor qualidade estrutural e organoléptica (lyengar et al., 1967). O teor de EST varia de 15,64\% (Nader Filho et al., 1986) a 17,95\% (Nader Filho et al., 1983) e é maior do que o EST encontrado para o leite bovino, o qual se situa em cerca de $12 \%$ (Verruma e Salgado, 1994).

O ESD do leite bubalino também apresenta característica semelhante às mencionadas para ao EST (lyengar et al., 1967). O teor de ESD do leite bubalino varia de 8,84\% (Verruma e Salgado, 1994) a 10,49\% (Furtado, 1980), sendo, portanto, maior do que o teor de ESD observado para o leite bovino (em torno de 8,5\%) (Verruma e Salgado, 1994). Outros pesquisadores encontraram resultados localizados dentro dos intervalos mencionados: 9,35\% (Antunes et al., 1988), 9,9\% (Nader Filho et al., 1986) e 10,18\% (Nader Filho et al., 1983).

A gordura representa um dos principais componentes do leite bubalino, juntamente com a proteína. Este leite possui teor de gordura maior do que o teor de 
gordura do leite bovino (Verruma \& Salgado, 1994). Da mesma forma que a densidade, a gordura também poderá sofrer influência durante o período de lactação atingindo valores entre 5,40 a 6,66\% (Nader Filho et al., 1996). No Brasil, há referência de percentuais de gordura no leite bubalino de até 8,16\% (Verruma \& Salgado, 1994).

Os glóbulos de gordura no leite de búfala possuem diâmetros maiores,

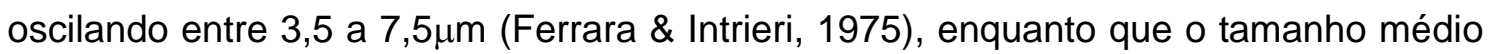
dos glóbulos de gordura do leite bovino varia de 3,6 a 4,0 $\mu$ m (Neves, 1985). Segundo Ferrara \& Intrieri (1975), os glóbulos de gordura adquirem dimensões menores nos estágios avançados da lactação e maiores durante a estação quente. De acordo com Dastur \& Laxminarayma (1968) o número de glóbulos de gordura é de 3,2 e 2,96 milhões $/ \mathrm{mm}^{3}$ no leite bubalino e bovino, respectivamente.

De acordo com Furtado (1980b), o maior percentual de proteínas em relação ao leite bovino constitui a principal vantagem na utilização do leite bubalino na fabricação de derivados, o que possibilita maior rendimento, principalmente de queijos. O teor de proteína total no leite bubalino poderá variar de 3,63 a 5,26\% (FAO, 1991). Segundo Verruma \& Salgado (1994), o valor encontrado para a proteína do leite de vaca $(3,7 \%)$ encontra-se próximo do limite mínimo dos valores mencionados para o leite de búfala.

A caseína é a principal proteína do leite, encontrando-se em maior proporção. A micela de caseína do leite de búfala possui diâmetro variando de 110 a 150nm, enquanto que a do leite de vaca apresenta diâmetro de 70 a 110 nm (Ferrara \& Intrieri, 1975). Comparativamente ao leite bovino, as micelas de caseína do leite de búfala são mais opacas, contêm menos nitrogênio, porém muito mais cálcio e fósforo (Ganguli, 1979).

A composição mineral do leite de búfala alcança valores entre 0,79 a 0,85\%, e encontra-se maior do que a composição mineral do leite de vaca (Ferrara \& Intriere, 1975). 
De acordo com Ferrara \& Intrieri (1975) o conteúdo de cálcio pode alcançar até 25\% do total da matéria mineral. Segundo Dastur \& Laxminarayma (1967) este conteúdo é maior no leite bubalino e ocorre em média de $0,18 \mathrm{~g} / 100 \mathrm{~mL}$. quando comparado com o leite de bovino, da mesma forma que os teores de cálcio e fósforo coloidal. O leite bubalino ainda possui elevadas concentrações de ânions quando comparado ao leite bovino (Ganguli, 1979).

No Brasil, o valor médio encontrado para o cálcio no leite bubalino é de 1,88\% (Verruma \& Salgado, 1994). O fósforo é encontrado no leite de búfala na proporção de $0,09-0,15 \mathrm{~g} / 100 \mathrm{ml}$ (Ferrara \& Intrieri, 1975).

\section{2- Características Microbiológicas do Leite de Búfala}

As características microbiológicas do leite de búfala são relativamente pouco conhecidas, quando comparado ao leite bovino, sobretudo no Brasil. É importante ressaltar que o leite bubalino in natura apresenta, também, elevada perecibilidade, e está sujeito às mesmas fontes de contaminação microbiana que podem existir na bovinocultura leiteira, principalmente na ordenha e no transporte do leite até a usina de processamento. Algumas peculiaridades do manejo e do comportamento das búfalas, entre outros fatores, podem contribuir para aumentar significativamente a carga microbiana inicial do leite cru, diminuindo assim a qualidade e a validade do produto e, por último, limitando o seu emprego pela indústria.

Os búfalos apresentam o costume de utilizar poças de água ou lama para se refrescar durante o dia, possibilitando a formação de uma camada fina de lama sobre a pele. Este comportamento confere proteção contra o estresse térmico e os insetos, dado que os búfalos possuem características peculiares em sua estrutura de termorregulação cutânea (pele mais espessa, menor densidade de folículos pilosos, somado aos pêlos esparsos) que dificultam a dissipação de calor corporal e oferecem pouca ou nenhuma proteção contra a radiação solar (Nascimento \& Carvalho, 1993). 
O hábito de imergir em coleções de água, no entanto, gera uma grande dificuldade para a obtenção higiênica do leite.

Diversos autores consideram que os hábitos comportamentais das búfalas dificultam a higienização do úbere e, conseqüentemente, favorecem a contaminação inicial do leite devido ao acúmulo de sujidades na glândula mamária. As contagens bacterianas no leite bubalino são aparentemente influenciadas, ainda, pelas condições climáticas das diferentes épocas do ano. Alguns trabalhos anteriores demonstram que as concentrações de microrganismos mesófilos, no leite recém-obtido, podem variar de $5,0 \times 10^{4}$ a $1,3 \times 10^{5}$ unidades formadoras de colônias/mililitro (ufc/mL.) no verão, e de $1,5 \times 10^{5}$ a 3,2 x 10 UFC/mL no inverno (Mallesappa et al., 1970; Garg et al., 1977, citados por Franciscis \& Di Palo, 1994). Sheata et al. (1982) relataram que a presença de bactérias formadoras de esporos no leite de búfalas variou de acordo com as estações do ano, sendo que as contagens alcançaram valores de 1,0 x $10^{3}$ a 9,9 $\times 10^{3}$ UFC/mL. Os trabalhos citados evidenciam a importância dos cuidados higiênicos nos momentos que antecedem a ordenha, com destaque para a limpeza e a desinfecção rigorosas do úbere dos animais.

A qualidade bacteriológica do leite "in natura" está intimamente relacionada com o tipo de manejo empregado no momento da ordenha. A adoção de técnicas adequadas de limpeza e sanitização de utensílios, equipamentos, úbere dos animais e instalações é essencial para a obtenção de leite com alta qualidade higiênica, ou seja, com reduzida contagem de microrganismos deteriorantes e ausência de espécies patogênicas (Fonseca \& Santos, 2000).

Nos rebanhos brasileiros, a obtenção do leite de búfala é feita predominantemente através da ordenha manual. A utilização de ordenhadeira mecânica pode ser interessante para rebanhos formados por animais de produção elevada, como acontece, por exemplo, na Itália, onde as criações apresentam altos índices de melhoramento genético e de produtividade (Franciscis \& Di Palo, 1994). A contaminação do leite obtido através da ordenha mecânica é, geralmente, inferior à do 
leite obtido pelo sistema de ordenha manual, possibilitando uma menor carga microbiana inicial do produto (Farmisano et al., 1980). Deve-se destacar, porém, que as ordenhadeira mecânicas não garantem, por si só, a qualidade microbiológica do leite, uma vez que os equipamentos necessitam dos mesmos cuidados higiênicos rigorosos no trabalho de ordenha. De qualquer modo, similarmente à ordenha manual, a implantação de sistemas de ordenha mecânica deve ser acompanhada de um treinamento adequado dos funcionários da propriedade, com vistas à obtenção de mão-de-obra qualificada para esta atividade (Fonseca \& Santos, 2000).

É importante ressaltar que contagens elevadas de microrganismos no leite cru acarretam problemas, não apenas para a conservação do produto antes de chegar ao laticínio, originando perdas por azedamento e outras alterações, mas também para a produção de derivados, gerando perdas na qualidade sensorial, microbiológica, além de diminuição da validade do produto (Oliveira et al., 1999). Apesar destes fatos, não existem atualmente, no Brasil, regulamentos que definam limites máximos para a contagem de microrganismos no leite de búfala entregue nos laticínios. A título de exemplo, Farmisano et al. (1980) relatam que contagens bacterianas elevadas, como por exemplo, acima de 1,0 × 107 UFC/mL, podem causar sérios prejuízos durante o processamento do leite, sobretudo no rendimento de obtenção do queijo tipo mozzarella.

\section{3- Características Gerais do logurte}

A palavra yogurt é derivada de jugurt, termo originário da Turquia que se consagrou universalmente para denominar o produto obtido a partir da fermentação do leite pelos microrganismos Lactobacillus delbrueckii subesp. bulgaricus e Streptococcus salivarius subesp. thermophilus (Tamime \& Deeth, 1980). Segundo a FAO (2003) os microorganismos no produto final têm que ser viáveis e abundantes.

O iogurte é o principal produto fermentado a partir do leite, sendo que existem diversos tipos elaborados com leite de búfala. Na Bulgária, utiliza-se o leite bubalino 
misturado ao bovino para a produção de um tipo especial de leite ácido, denominado kúselo mleko, elaborado com L. bulgaricus, similarmente ao iogurte de leite de búfala produzido na Itália (Ferrara \& Intrieri, 1975).

Na Índia, é elaborado um produto com características semelhantes ao iogurte, conhecido por dahi, podendo ser utilizado como matéria-prima o leite de vaca, de búfala ou o produto da mistura dos dois. É o produto lácteo fermentado mais importante consumido em todo território indiano. O dahi é produzido com diversos microrganismos, além dos usualmente empregados na elaboração do iogurte tradicional Ganguli (1979).

A elaboração de produtos fermentados com leite bubalino é particularmente elevada na Índia, a qual destina cerca de $7 \%$ do leite bubalino à produção de um tipo de leite fermentado denominado khoa, cujas características de textura decorrem do alto teor de gordura (7-8\%) no produto, elaborado com leite integral (Ganguli, 1979).

Toda esta variedade de leites fermentados teve sua origem provavelmente pelas distintas exigências climáticas e ambientais dos microrganismos que favoreceram o desenvolvimento deste processo. É importante destacar que os derivados citados compreendem produtos regionais, cujas características são ajustadas de acordo com as preferências locais.

Os diversos tipos de leites fermentados são processados utilizando tecnologias semelhantes e, em muitos casos, as diferenças se limitam ao tipo de microrganismo empregado no cultivo e o conteúdo de sólidos totais do leite. No caso do iogurte, a FAO (2003) tem recomendado que o ESD no leite original apresente um valor mínimo de $8,2 \%$, para que o iogurte tradicional permaneça com as suas características sensoriais semelhantes, independentemente da região onde é produzido.

O iogurte pode ser classificado quanto ao seu teor de gordura em: iogurte com creme (mínimo de 6,0\%), iogurte integral (mínimo de 3,0\%), iogurte parcialmente desnatado (entre 0,5\% e 2,9\%), e iogurte desnatado (máximo de 0,5\%) (Brasil, 1996).

A utilização do leite de búfala para a produção industrial de iogurtes tem sido 
pouco reportada na literatura.

lyengar et al (1967) observaram a influência do tratamento térmico no iogurte elaborado com leite integral bubalino e bovino, analisando as características sensoriais do produto final. Os autores concluíram que o iogurte elaborado com leite integral bubalino apresentou um corpo e uma textura mais firme, enquanto o iogurte elaborado com leite bovino apresentou as melhores notas para o sabor.

Yabu et al. (1988) estudaram a incorporação de leite de búfala ao leite bovino, analisando a composição físico-química e sensorial do iogurte produzido com misturas de leite bovino e bubalino, em diferentes proporções (70\%, 50\% e 30\% de leite bubalino). Os autores concluíram que a introdução do leite bubalino, nas proporções de $50 \%$ e $30 \%$, incrementou o sabor e a consistência do produto, ao passo que o iogurte produzido com $70 \%$ de leite de búfala apresentou desempenho inferior na avaliação sensorial. Estes dados sugerem a necessidade de padronização do leite bubalino destinado à elaboração do iogurte, particularmente do teor de gordura.

Queiroz et al. (2002) recomendaram a utilização do iogurte de leite de búfala, contendo ou não polpa de frutas da Amazônia (cupuaçu e bacuri), como substituto da merenda escolar de crianças entre a $1^{\mathrm{a}}$ a $4^{\mathrm{a}}$ séries, uma vez que o produto, além de saboroso, apresenta quantidade de calorias superior às necessidades diárias das crianças para a refeição citada. Os autores concluíram que esta prática constitui uma excelente alternativa para o aproveitamento de safras de frutas regionais, além de contribuir para implantação de programas de alimentação para estudantes e comunidades carentes.

Não há referências de estudos sobre o emprego de técnicas de padronização do leite bubalino destinado à elaboração de leites fermentados, com exceção do trabalho de Chawla \& Balachandran (1994), os quais avaliaram características reológicas e sensoriais do iogurte de leite de búfala contendo diferentes níveis de sólidos totais. 


\section{4- Tecnologia de Produção do logurte}

As etapas de produção do iogurte incluem, de modo geral, verificação das características do leite original, padronização dos teores de gordura e, eventualmente, de extrato seco, tratamento térmico, semeadura, incubação e embalagem do produto final. O leite destinado à elaboração do iogurte deve apresentar características peculiares que proporcionem o desenvolvimento microbiano sem causar nenhuma alteração nas suas características físico-química, microbiológica, reológica e sensorial. O elevado teor de sólidos totais no leite é desejável para proporcionar produto com características peculiares ao produto. O nível recomendado de EST empregado na elaboração de iogurte de leite de vaca encontra-se entre 14 e 18\% (Tamime \& Deeth, 1980).

Adicionalmente, resíduos de antimicrobianos e de desinfetantes devem estar ausentes, uma vez que sua presença causa inibição dos microrganismos empregados na elaboração do iogurte, com posterior aumento no tempo de incubação. A presença de antimicrobianos constitui, também, um grave problema de Saúde Pública (Tamime \& Deeth, 1980; Brandão, 1995).

A padronização do ESD pode ser obtida misturando-se ao leite integral, leite em pó desnatado, proteínas de soro de leite, adição de caseinato, utilização de centrífugas separadoras, evaporação a vácuo, ultrafiltração através de membranas, osmose reversa (Tamime \& Deeth, 1980) e emprego de leite concentrado (Spreer, 1991). A padronização do ESD é adotada regularmente na indústria com a finalidade de reforçar os sólidos, principalmente no caso do leite bovino, com a finalidade de aumentar o valor nutritivo e calórico, bem como melhorar as características organolépticas e reológicas do produto (Spreer, 1991; Robinson \& Tamime, 1993; Brandão, 1995).

O desnatamento é realizado através da centrifugação do leite, na qual uma porção livre de gordura (leite desnatado) é separada de uma porção rica em gordura devido à diferença de densidade de ambas (Spreer, 1991). Trata-se, portanto, de um 
processo físico de separação dos glóbulos de gordura, cujos principais objetivos são: a obtenção de produtos que contenham quantidade parcial ou que sejam totalmente desprovidos de gordura e a obtenção de produtos com seu teor de gordura padronizado (Spreer, 1991).

Após a preparação do leite, são aplicados os tratamentos térmicos usualmente recomendados para a elaboração de produtos fermentados. Segundo Tamime \& Deeth (1980) e Robinson \& Tamime (1993) os valores de temperatura e tempo recomendados para a fabricação do iogurte são $85^{\circ} \mathrm{C} / 30$ minutos. Spreer (1991) afirma que um ótimo tratamento térmico consiste em aquecer o leite à temperatura de $90^{\circ} \mathrm{C} / 30$ minutos. Os principais efeitos do tratamento térmico no leite empregado na elaboração de iogurtes incluem: eliminação de microrganismos contaminantes que poderiam competir com a cultura; desnaturação das proteínas do soro, agregação e inativação de imunoglobulinas; produção de grupos sulfidrílicos; interações entre a $\beta$ caseína e a k-caseína que minimizam o aparecimento da separação do soro do coágulo (sinérese) (Burki \& Blanc, 1978; Elfgam \& Wheelock, 1978b).

Outros benefícios do tratamento térmico são, a hidrólise em lipídeos (proporcionando a formação de lactona, metil cetona e outros compostos voláteis) que contribui para o sabor (Tamime \& Deeth, 1980), redução nos níveis dos gases dissolvidos, oxigênio, nitrogênio e dióxido de carbono (proporcionando ambiente favorável ao crescimento da cultura starter), redistribuição de minerais, $\mathrm{Ca}, \mathrm{P}$ e $\mathrm{Mg}$, entre os estados solúvel e coloidal (favorece a diminuição no tempo necessário para a formação do coágulo) (Tamime \& Deeth, 1980; Robinson \& Tamime, 1993).

Os microrganismos utilizados na elaboração dos iogurtes compreendem as espécies Streptococcus salivarius subsp. termophilus e o Lactobacillus delbrueckii subsp. bulgaricus (Spreer, 1991). Estes microrganismos possuem características distintas, sendo que as modificações que transformam o leite em iogurte decorrem da ação simbiótica entre ambos os tipos. O S. salivarius subsp. termophilus apresenta-se formando pares (diplococos) ou cadeias mediamente largas e esféricas, com diâmetro 
aproximado de 0,7 a $0,9 \mu \mathrm{m}$. Os cocos possuem temperatura ótima de crescimento entre 37 e $42^{\circ} \mathrm{C}$ e atividade máxima aproximada quando o iogurte apresenta $0,8 \%$ de ácido lático (Spreer, 1991). Já o L. delbrueckii subsp. bulgaricus apresenta-se como bastonetes relativamente largos, com tamanho entre 0,2 a $0,4 \mu \mathrm{m}$. Os bacilos possuem uma temperatura ótima de crescimento entre 42 e $45^{\circ} \mathrm{C}$ e atividade máxima quando o iogurte apresentar entre 1,5 e 2,0\% de ácido lático (Spreer, 1991).

Recomenda-se, geralmente, a temperatura de incubação entre $42-42,5^{\circ} \mathrm{C}$, com acidez final suave e moderada, variando de 0,8 a 0,9\% de ácido lático. A atividade de acidificação da combinação dos dois microrganismos é superior à atividade de acidificação de cada um deles separadamente (Mocquot \& Hurel, 1970; Spreer, 1991).

No início da incubação, em um pH acima de 5,5, o S. thermophilus cresce rapidamente estimulado pela produção de alguns aminoácidos (glicina, histidina e valina) liberados pelo L. bulgaricus, mas como a acidez diminui, a multiplicação das células vagarosamente decresce até estacionar em um $\mathrm{pH}$ aproximado de 4,2. O L. bulgaricus cresce mais lentamente no início pela produção de substâncias (exemplo: ácido fórmico) pelo S. thermophilus (Brandão, 1995).

O desenvolvimento das culturas durante a incubação é caracterizado, também, pela formação de acetaldeído, principal substância que confere o aroma típico nos iogurtes. O acetaldeído é produzido pelo L. bulgaricus (Mocquot Hurel, 1970). Outros compostos presentes, elaborados por culturas mistas, e que também participam da formação do aroma e do sabor em iogurtes são, a acetoína, a acetona, 2-butanona, o diacetil e o etanol (Beshkova et al, 1998).

A preparação da cultura mãe e dos cultivos intermediários deve ser realizada em condições de laboratório, em uma câmara asséptica, ou então em uma instalação independente das destinadas à elaboração do iogurte.

A proporção esperada dos microrganismos, tanto da cultura mãe, como nas culturas intermediárias e no iogurte, é de 1:1 a 2:3. As características organolépticas próprias do iogurte, tais como o sabor, o odor, a consistência, o aspecto e a cor são 
realçadas quando esta proporção encontra-se presente no produto final (Spreer, 1991). A elaboração de iogurte leite de búfala integral utilizando um período de incubação de 270 minutos não altera a microbiota da população no produto final (Scholz \& Antunes, 1996).

Os microrganismos empregados na elaboração do iogurte são adquiridos, geralmente, sob a forma liofilizada, uma vez que são de fácil manipulação, possibilitando um controle eficaz nas propriedades finais do iogurte (Varnam \& Sutherland, 1994). A cultura mãe é preparada através de semeadura direta em um litro de leite previamente aquecido a $90^{\circ} \mathrm{C}$ por 30 minutos, seguido de incubação a 43 a $45^{\circ} \mathrm{C}$ por cerca de três horas, até alcançar o pH de 4,5 a 4,65 (Spreer, 1991).

A última etapa de produção do iogurte natural é o envasamento, que normalmente é precedido pelo resfriamento e agitação do coágulo, para a obtenção do produto classificado como batido. No caso de iogurtes com sabor, o processo de agitação é feito juntamente com a adição de complementos, tais como polpa de frutas, substâncias aromáticas e corantes. A operação de envase é considerada crítica, devido aos riscos de contaminação microbiana do produto pronto (Lewis \& Dale, 1996). Em condições ideais, o envase final do iogurte deve realizar-se imediatamente depois do resfriamento até temperaturas inferiores a $20^{\circ} \mathrm{C}$ (Varnam \& Sutherland, 1994).

Os iogurtes embalados devem ser submetidos ao resfriamento o mais rápido possível, a fim de evitar a acidificação pós-processamento. O resfriamento deverá alcançar uma temperatura de $15^{\circ} \mathrm{C}$ entre um período de 1,5 a 2 horas, após o período de incubação. Esta deve ser controlada cuidadosamente para evitar a formação rápida e demasiada da sinérese (Varnam \& Sutherland, 1994). Uma vez realizada a prérefrigeração, o iogurte deverá ser conservado em câmara a $5^{\circ} \mathrm{C}$, para que ocorra a formação do aroma em aproximadamente 2 horas. Transcorridos de 10 a 12 horas de armazenamento, o iogurte estará pronto para a expedição (Spreer, 1991). 


\section{5- Parâmetros de Qualidade do logurte}

A qualidade do iogurte está diretamente relacionada ao monitoramento de todas as etapas de sua fabricação, desde a verificação da composição físico-química e das características microbiológicas da matéria-prima, até o controle das etapas de elaboração (tratamento térmico, culturas lácteas utilizadas, condições de inoculação e incubação, resfriamento e envase) e armazenagem. É possível agrupar os parâmetros de qualidade do iogurte em diferentes categorias, com destaque para as seguintes: microbiológica, físico-química, reológica e sensorial.

\subsection{1- Parâmetros Microbiológicos}

As análises microbiológicas são utilizadas para comprovar se ocorreu desenvolvimento adequado dos microrganismos empregados na elaboração do iogurte, bem como para verificar se as condições higiênicas no processamento foram satisfatórias (Varnam \& Sutherland, 1994). A análise microbiológica mais comumente empregada na avaliação do iogurte é determinação de coliformes totais e fecais (BRANDÃO, 1996). É importante, também, a análise dos microrganismos empregados na elaboração do produto para verificar o adequado crescimento dos mesmos durante a incubação.

De acordo com a International Dairy Federation (1988), países como a França e Espanha estabeleceram que o mínimo de bactérias ácido-láticas viáveis durante o período de vida-de-prateleira é de $10^{5} \mathrm{ufc} / \mathrm{mL}$. Outros países estabeleceram valores de $10^{6} \mathrm{ufc} / \mathrm{mL}$ (Suíça e Itália), $10^{7}$ ufc/mL. (Japão) e $10^{8} \mathrm{ufc} / \mathrm{mL}$. (Portugal). O Mercosul estabeleceu que o limite mínimo de bactérias ácido-láticas viáveis é da ordem de $10^{7}$ ufc/mL (Mercosul, 2003).

Segundo Tamime \& Robinson (1985) o número de microrganismos viáveis na microbiota do iogurte para a obtenção das características próprias e desejáveis ao produto final deve estar acima de $10^{7} \mathrm{ufc} / \mathrm{mL}$. Scholz \& Antunes (1996) observaram que os iogurtes provenientes de leite integral bovino ou bubalino, e o produto da 
mistura de ambos, apresentaram números compatíveis com os parâmetros citados para a população microbiana, demonstrando, portanto, que a adição de leite de búfala não alterou a microbiota do iogurte. De acordo com Moreira et al. (1999) a população microbiana viável, em iogurte natural comercializado em Lavras/MG, encontra-se na ordem de 1,2 a $3,0 \times 10^{7}$ ufc/mL.

Entre os microrganismos indesejáveis no iogurte, deve-se destacar as bactérias psicrotróficas, as quais provocam alterações nas características organolépticas de derivados lácteos quando encontram-se em níveis em torno de $10^{6}$ ufc/ml (Cousin, 1982) a 107 ufc/ml (Shelley et al., 1987; Cromie, 1992). De acordo com Sørhaug \& Stepaniak (1997), contagens elevadas de psicrotróficos (7,6 a 7,8 Log UFC/mL) no leite utilizado como matéria-prima, antes do tratamento térmico, pode ser indicativo de modificações no sabor e odor dos iogurtes. Estas alterações são decorrentes, sobretudo, da lise de ésteres, fosfolípideos, glicídios, lipídeos e proteínas pelas enzimas termoresistentes produzidas pelos psicrotróficos no leite in natura antes do tratamento térmico, ou por enzimas produzidas pelo crescimento destes microrganismos durante a fase de refrigeração dos produtos lácteos (Sørhaug \& Stepaniak, 1997). Contudo, não foram encontrados trabalhos na literatura sobre a ocorrência de psicrotróficos em iogurte elaborado com leite bubalino.

A classificação da ocorrência de microorganismos em iogurtes, preconizada por Davis et al. (1971) citados por Brandão (1996), determina que a presença de menos de um coliforme total $/ \mathrm{mL}$ no iogurte é tida como a ideal.

A análise dos coliformes visa verificar se houve contaminação pósprocessamento, pois estes microrganismos são facilmente destruídos durante a pasteurização (Souza, 1996).

As transformações bioquímicas que ocorrem durante a etapa da incubação promovem o abaixamento do $\mathrm{pH}$ a níveis não suportáveis pelos coliformes. A redução dos níveis de contaminação por coliformes, variando entre $10^{2}$ e $10^{5}$ coliformes $/ \mathrm{mL}$, ocorrida em iogurte elaborado com leite bubalino, são reduzidas drasticamente e 
impedem que os mesmos não apresentassem células viáveis após 15 dias de sua produção quando em pH ácido (Ghani et al., 1998). Resultados segundo Queiroz et al. (2002), não há crescimento de coliformes 21 dias após o processamento, em iogurte natural elaborado com leite de búfala, adicionando sabores de frutas regionais da Amazônia.

\subsection{2- Parâmetros Físicos e Químicos}

No que concerne às características físico-químicas, poucos trabalhos foram desenvolvidos com o intuito de estudar as variações na acidez do iogurte de leite bubalino ou de misturas deste com o leite bovino. Yabu et al. (1988) e Scholz \& Antunes (1996) observaram que o iogurte produzido a partir de leite integral de búfala apresentou variações na acidez de 0,78 a 1,21\% (expresso em g de ácido láctico/100 $\mathrm{g}$ de iogurte) respectivamente. O iogurte integral de leite bovino e o produzido com $50 \%$ de leite bovino e bubalino apresentaram valores de 0,87 a 1,27\% e 0,86 a 1,31\%, respectivamente.

De acordo com os dados disponíveis na literatura, os iogurtes elaborados com o emprego de leite integral bovino podem desenvolver acidez entre 0,7 a 1,09\% (Moreira et al., 1999). Souza (1996) considera uma acidez de 0,9\% de ácido lático, essencial para o desenvolvimento do sabor e aroma peculiares ao iogurte.

As variações do $\mathrm{pH}$ de iogurtes produzidos com leite bubalino e suas diluições com o leite bovino apresentam resultados entre 4,03 (Scholz \& Antunes, 1996) a 4,74 (Yabu et al., 1988). Valores semelhantes para a acidez do iogurte são observados quando estes são produzidos com leite integral de bovinos $(4,08$ e 4,45), ou com 0 produto de sua mistura (50\%/50\%) com o leite bubalino, 4,06 e 4,47 respectivamente (Yabu et al., 1988; Scholz \& Antunes, 1996).

Yabu et al. (1988) estudaram as características físico-químicas e sensoriais de iogurte produzido de misturas de leite bovino e bubalino e concluíram que, mesmo sendo uma alternativa viável, a introdução do leite bubalino ao leite bovino para a 
produção de iogurte deve ser acompanhada de um rigoroso processo no controle do teor de gordura, pois parece haver uma relação entre a preferência e o aumento na proporção de leite de búfala nas misturas, após 50\%. Segundo Furtado (1980), é essencial que o leite de búfala destinado à elaboração do iogurte tenha o seu teor de gordura reduzido, a fim de contribuir decisivamente para a melhoria deste produto.

A composição do iogurte é, de modo geral, similar à composição do leite que Ihe deu origem, com pequenas variações. Por este motivo, o iogurte de leite bubalino apresenta níveis mais elevados dos seus componentes nutricionais, quando comparado ao iogurte de leite bovino. Assim, Verruma et al. (1993) encontraram os teores de gordura e proteína de 7,1\% e 4,5\%, respectivamente, para o iogurte produzido com leite integral bubalino. Segundo lyengar et al. (1967) e Verruma et al. (1993), o iogurte produzido com leite bubalino pode apresentar-se com um teor de EST variando de 16,0 a 18,9\%, respectivamente.

\subsection{3- Parâmetros Reológicos}

A reologia pode ser genericamente definida como o estudo da deformação da matéria ou, ainda, o estudo da mobilidade dos fluídos (Bobbio \& Bobbio, 2001). A reologia dos fluidos é estudada, principalmente, através da viscosidade (Bobbio \& Bobbio, 2001).

A viscosidade é a medida da resistência ao movimento (deformação) das várias camadas paralelas de um fluido, movendo-se laminarmente com um gradiente de velocidade uniforme, de separação dessas camadas, quando sob a ação de uma tensão (força) deformante F. Durante o movimento, as camadas se mantêm paralelas sem turbilhonamento. A viscosidade do fluido é expressa pelo coeficiente da viscosidade, cuja unidade é denominada centiPoise (cP), correspondendo à viscosidade de um fluido que escorre à velocidade de um $\mathrm{cm} / \mathrm{s}$ quando sujeito a uma força de um dina $/ \mathrm{cm}^{2}$ ou um $\mathrm{m} / \mathrm{s}$ para uma força de um newton $/ \mathrm{m}^{2}$ (Bobbio \& Bobbio, 2001). 
A dinâmica da viscosidade de fluidos é mensurada pelo emprego de viscosímetros (de fluxo ou rotacional) segundo Lewis (1994). Entre os viscosímetros rotacionais, provavelmente o mais amplamente empregado é o modelo Brookfield. Este viscosímetro utiliza um tensor de cisalhamento (spindle) fixado em uma região central que, rotacionado por um motor incidindo no líquido teste, promove a força requerida para estabelecer a fricção a ser mensurada (Lewis, 1994).

De acordo com Tamime \& Deeth (1980), a viscosidade do iogurte depende totalmente do conteúdo de proteína do leite. Uma elevação na concentração de proteína é essencial para a produção de um iogurte com uma viscosidade adequada.

As proteínas contribuem com cerca de $35 \%$ do ESD do leite e a caseína com cerca de $85 \%$ desse total. O autor afirma que o elevado teor de caseína no leite de vaca proporciona maior viscosidade no iogurte (Brandão, 1996), todavia é bem aceito que a desnaturação das proteínas do soro aumenta a firmeza e a viscosidade do iogurte (Tamime \& Deeth, 1980).

A viscosidade do iogurte tradicional deve apresentar-se relativamente alta, ser capaz de determinar uma sensação macia, suave e agradável no palato e, sobretudo, estar livre de grânulos e pedaços de coágulo (Souza, 1996). Shaker et al. (2000) estudaram as possíveis alterações na viscosidade com o emprego de diferentes tratamentos térmicos $\left(137^{\circ} \mathrm{C}\right.$ por 2 segundos, $90^{\circ} \mathrm{C}$ por 3 minutos, e $65^{\circ} \mathrm{C}$ por 30 minutos) e teores de gordura $(0,2 \%, 0,8 \%, 1,5 \%$, e $3,0 \%)$ no leite destinado à elaboração de iogurtes. Os autores concluíram que a viscosidade do leite poderá aumentar progressivamente com o aumento da temperatura e do teor de gordura.

Outros fatores podem, também, ocasionar modificações na viscosidade, tais como a homogeneização do leite, o tipo de cultivo lácteo e sua respectiva linhagem (Tamime \& Deeth, 1985; Benezech \& Maingonnat, 1994), o bombeamento e o transporte do iogurte por meio de tubos até o envasamento (Benezech \& Maingonnat, 1994). De acordo com Tamime \& Deeth (1985) a adição de estabilizadores e o aprimoramento no sistema de processamento do iogurte também influenciam na 
viscosidade do iogurte.

No Brasil, os principais tipos de iogurtes encontrados no mercado consistem no iogurte batido ou Suíço, fermentado no pote e o iogurte líquido (Brandão, 1995). Esta classificação leva em consideração o aspecto físico do coágulo, o qual varia principalmente de acordo com a viscosidade do mesmo.

O iogurte fermentado no pote é o que apresenta a textura mais firme, de forma que possa ser removido do copo e consumido com o auxílio de uma colher. O iogurte batido e o líquido apresentam-se com uma viscosidade menor, os quais apresentam maior aceitação pelos consumidores (Brandão, 1995).

As diferenças na estrutura física do coágulo do iogurte podem estar relacionadas a diferentes propriedades do gel, concentrações ou estruturas de exopolissacarídeos, pelas ligações entre os exopolissacarídeos e proteínas, ou ainda pelo tratamento térmico empregado (Kim \& Kinsella, 1989).

Com relação à viscosidade do iogurte produzido com leite bubalino, o único trabalho disponível é o de Chawla \& Balachandran (1994), os quais obtiveram valores crescentes deste parâmetro no iogurte contendo sólidos totais de 9,0 a 15,0\%. Os autores concluíram que os melhores resultados de viscosidade e de avaliação sensorial foram relativos ao produto elaborado com leite contendo 10,0\% de sólidos totais.

\subsection{4- Parâmetros Sensoriais}

São poucos os trabalhos que abordam a avaliação sensorial de iogurte produzido com leite de búfala. Alguns estudos indicam uma preferência menor pelo sabor do iogurte produzido com leite integral bubalino, em relação ao leite integral bovino (lyengar, 1967). Entretanto, na Índia, Chawla \& Balachandran (1994) observaram que o iogurte de leite de búfala contendo 3,0\% de gordura apresentou bom desempenho na avaliação sensorial realizada por provadores treinados.

A principal substância que colabora para o aroma e o sabor típico do iogurte é 
o acetaldeído, o qual é produzido pelos microrganismos durante a incubação (Tamime \& Deeth, 1980). A participação de outros compostos na formação do aroma e do sabor, como acetoína, acetona, 2-butanona, diacetil e etanol ocorrem em menores quantidades (Beshkova et al, 1998). As culturas lácteas também podem produzir quantidades excessivas de acetaldeído que são responsáveis pelo aparecimento do sabor e aroma de malte (Souza, 1996). Outros atributos sensoriais importantes na avaliação do iogurte incluem a consistência e o aspecto geral do produto.

Basicamente, os métodos sensoriais são agrupados em analíticos e afetivos. Os métodos analíticos são usados em avaliações onde é necessária a seleção e/ou treinamento da equipe sensorial e em que é exigida uma avaliação objetiva, ou seja, na qual não são consideradas as preferências ou opiniões pessoais dos membros da equipe, como no caso dos testes afetivos (IFT, 1981). Estes últimos, por outro lado, constituem uma importante ferramenta, pois acessam a opinião (preferência e/ou aceitabilidade) do consumidor sobre características específicas de um determinado produto.

A característica principal de um painel sensorial, em testes afetivos, é que estes devem ser conduzidos por um grupo de pessoas (juizes/provadores) selecionadas como uma amostragem representativa de uma população maior, no caso o mercado consumidor, sobre a qual o analista espera tirar algumas conclusões. Este grupo deve ser composto por consumidores em potencial do produto a ser testado, uma vez que os bens de consumo e serviços são direcionados para atingir populações alvo, mercados selecionados ou segmentos da população cuidadosamente selecionados (Ferreira et al., 2000).

De uma forma geral, para o método afetivo geralmente são coletadas de 50 a 300 respostas (pessoas) em cada local onde o teste é realizado. Neste caso, como o potencial de distração pode ser alto, as instruções e as questões devem ser claras e concisas (Ferreira et al., 2000). Uma vez constituído o painel, os avaliadores não devem receber treinamento especial e as amostras em número de uma, duas ou no 
máximo três, são distribuídas nas condições mais próximas do consumo normal.

Deve-se ressaltar, por último, que os membros do painel não devem receber nenhuma instrução que venha a influenciar na identificação de uma determinada amostra e nem no resultado que se pretende obter do teste. Por outro lado, devem receber instruções claras quanto ao sistema de avaliação que está sendo usado e dos atributos que devem ser considerados na avaliação. É importante também que os juizes permaneçam em cabines isoladas para que o membro do painel possa se concentrar sem ser influenciado pelos ruídos, palavras ou expressões estranhas de outros membros. É essencial que a iluminação seja uniforme e normal, principalmente quando a cor do produto tem importância na avaliação de sua qualidade. 


\section{3- MATERIAL E MÉTODOS}

\section{1- Obtenção do Leite}

O leite utilizado no presente experimento foi fornecido pelo rebanho bubalino da fazenda Betel, localizada no Município de São Carlos. O leite retirado era referente à ordenha da mesma manhã e já estava previamente refrigerado. Este leite foi ordenhado manualmente das búfalas em final de lactação, porém com uma boa higienização no momento da ordenha. Em cada dia de processamento, foram recolhidos 90 litros de leite em latões de polipropileno higienizados (capacidade 50 litros) e, na chegada ao Laticínio-Escola do Campus da USP em Pirassununga, eram imediatamente transferidos para câmara fria a $5^{\circ} \mathrm{C}$, para armazenamento até $\mathrm{o}$ momento de sua utilização. A colheita de leite foi repetida cinco vezes durante o experimento, o que permitiu a elaboração de cinco lotes de iogurte para cada um dos tratamentos descritos no item 3.3.

As condições sanitárias do leite produzido no estábulo da Fazenda foram avaliadas antes do início do experimento, através da colheita asséptica de duas amostras (500 mL cada), retiradas diretamente dos latões (cerca de 15 min. após a ordenha), durante sete dias seguidos. As amostras foram submetidas à contagem de microrganismos mesófilos e psicrotróficos (APHA, 1992), para o controle da matéria prima inicial aceitável para a elaboração do iogurte. Os resultados são apresentados na Figura 1.

As contagens obtidas nos primeiros dias de amostragem revelaram-se muito elevadas, em torno de 7 Log. de ufc/mL. Entretanto, com o reforço das medidas de higiene e sanitização dos procedimentos de ordenha, foi possível reduzir a contagem de mesófilos para níveis em torno de 6 Log. de ufc/ml, ou seja, um ciclo logarítmico abaixo dos valores iniciais. Os procedimentos de higienização foram mais eficientes na redução da contagem de psicrotróficos, que passou de 4 Log. de ufc/ml para valores 
em torno de 2 Log. de ufc/ml, o que permitiu considerar o leite aceitável como matéria prima para a elaboração do iogurte.

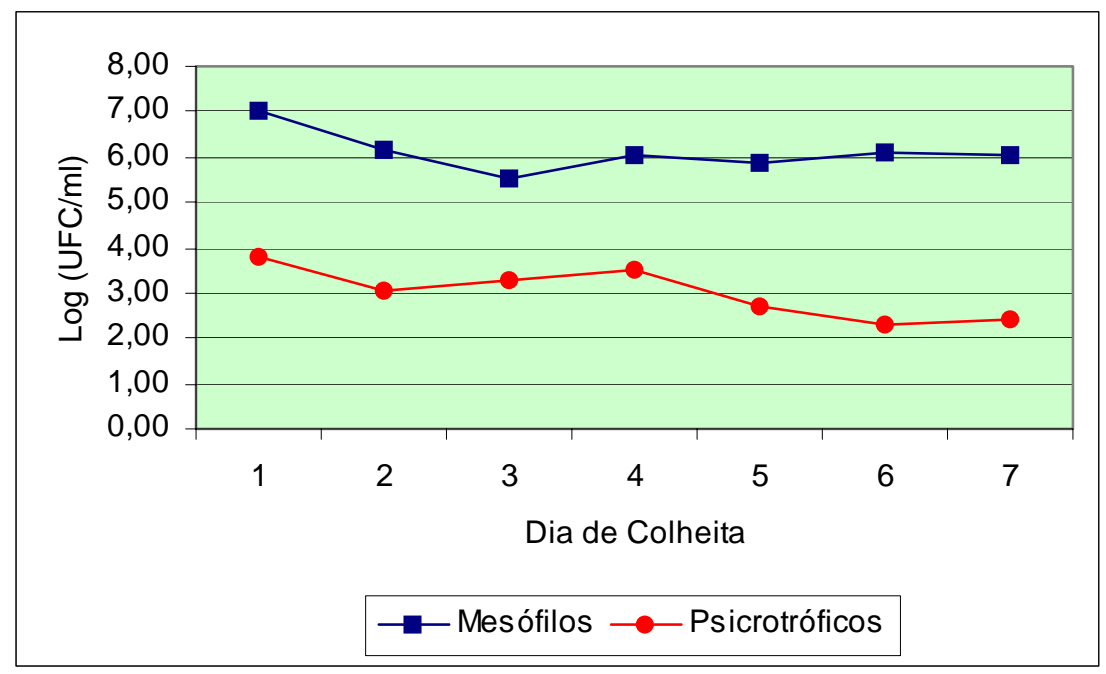

Figura 1. Evolução dos níveis (Log ufc/ml) de microrganismos mesófilos e psicrotróficos no leite de búfala cru, previamente ao início do experimento.

\section{2- Realização de Análises Prévias do Leite}

Após a chegada ao Laticínio-Escola, o leite contido nos latões foi homogeneizado por agitação para colheita de amostras individuais, as quais constituíram um pool para fins de realização das seguintes análises físico-químicas (IAL, 1985), em duplicata:

- $\mathrm{pH}$, determinado em pH-metro digital de marca Tecnal Modelo Tec 2;

- acidez ( $\left.{ }^{\circ} \mathrm{D}\right)$, conforme método clássico de Dornic;

- percentual de gordura, determinado pelo método de Gerber;

- percentual de proteína, determinado pelo método clássico de Kjeldahl;

- densidade, determinada pelo termolactodensímetro de Quevene a $15^{\circ} \mathrm{C}$;

- índice crioscópico, determinado em crioscópio eletrônico ITR modelo MK 540, sendo o resultado convertido para $^{\circ} \mathrm{C}$, de acordo com Fonseca \& Santos (2000);

- extrato seco total (EST) através de Fórmula de Fleischmann ;

- extrato seco desengordurado (ESD) por diferença do EST - G\%; 
Adicionalmente, foram efetuadas análises microbiológicas nas amostras de leite, com vistas à contagem de mesófilos, psicrotróficos e determinação do NMP de coliformes totais e fecais (APHA, 1992).

\section{3- Desnatamento e Padronização do Teor de Gordura}

Para tanto, parte do leite bubalino integral foi aquecido a cerca de $50^{\circ} \mathrm{C}$ e submetido à centrifugação em desnatadeira aberta (capacidade de 225L/h) (Figura 2) para a obtenção de leite desnatado ( $0,5 \%$ de gordura) e creme. Os tratamentos consistiram da elaboração de iogurtes de leite bubalino com diferentes teores de gordura, de acordo com o que se segue:

Tratamento A: Leite integral, sem modificação no teor de gordura;

Tratamento B: Leite padronizado com 3,0\% de gordura;

Tratamento C: Leite desnatado, contendo $0,5 \%$ de gordura.

A padronização do leite do Tratamento B foi realizada através da mistura de leite integral e leite desnatado, fazendo-se o cálculo das quantidades de cada um de acordo com Spreer (1991), através da seguinte fórmula:

$$
m_{L I}=\left[m_{L D} \times\left(g_{E L P}-g_{L D}\right)\right] /\left(g_{L I}-g_{E L P}\right), \text { onde: }
$$

$\mathrm{m}_{\mathrm{LI}}=$ peso do leite integral a ser adicionado (em $\left.\mathrm{kg}\right)$;

$\mathrm{m}_{\mathrm{LD}}=$ peso teórico do leite desnatado a ser padronizado (em $\left.\mathrm{kg}\right)$;

$g_{\mathrm{ELP}}=$ conteúdo de gordura esperado no leite após padronização (em \%);

gLD = conteúdo de gordura medido no leite desnatado (em \%).

$g_{\mathrm{LI}}=$ conteúdo de gordura no leite integral (\%). 


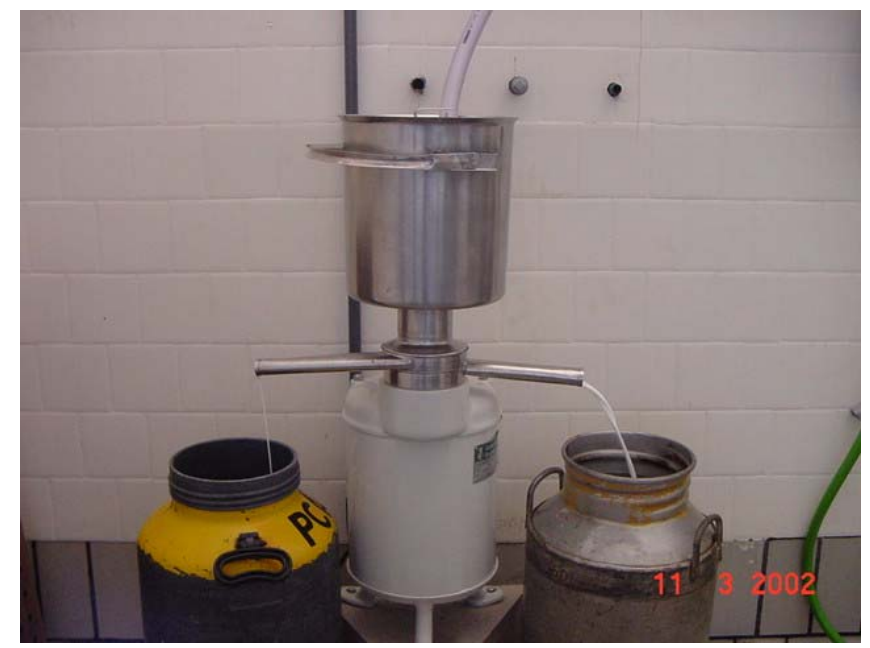

Figura 2. Desnatadeira utilizada para a separação do creme do leite de búfala.

\section{4- Elaboração do logurte Natural Batido}

Os três tipos de leite, obtidos nas condições estabelecidas no item anterior, foram utilizados para a fabricação dos Tratamentos (A, B, e C) do iogurte batido, a qual foi realizada no Setor de Laticínio-Escola do Campus de Pirassununga. Cada tipo de leite foi processado separadamente, no mesmo dia. Para isto, foram obedecidos os procedimentos descritos por Spreer (1991), para a elaboração do iogurte batido, e detalhado a seguir.

\subsection{1- Tratamento Térmico do Leite}

O conteúdo total máximo foi de 28 litros de leite para cada lote produzido em cada tratamento. Tal volume foi vertido na cuba da iogurteira disponível no Laticínio e submetido ao aquecimento a $90^{\circ} \mathrm{C}$ por 15 minutos no próprio equipamento, após o que era resfriado até cerca de $45^{\circ} \mathrm{C}$. Após este procedimento, foram colhidas duas amostras do leite para exame microbiológico (contagem de mesófilos, psicrotróficos e NMP de coliformes totais e fecais). A eficiência do tratamento térmico foi avaliada através da análise de peroxidase (Instituto Adolfo Lutz, 1985). 


\subsection{2- Semeadura, Incubação e Embalagem}

O cultivo lácteo (VISBYVAC $\left.{ }^{\circledR}\right)$ foi adquirido na forma liofilizada, contendo as bactérias termofílicas Streptococcus salivarius ssp. thermophilus e Lactobacillus delbruekii ssp. bulgaricus. A cultura mãe foi preparada através de semeadura direta em um litro de leite previamente aquecido a $90^{\circ} \mathrm{C}$ por 30 minutos, seguido de incubação a $42^{\circ} \mathrm{C}$ por aproximadamente três horas, até alcançar o valor de pH de 4,54,65. Esta cultura era mantida em temperatura inferior a $10^{\circ} \mathrm{C}$, sendo utilizada para $\mathrm{o}$ preparo do cultivo starter no dia de produção do iogurte, através da semeadura de 23\% em um litro de leite, nas mesmas condições descritas anteriormente. Todos os procedimentos para o preparo e manutenção dos cultivos foram realizados fora da área de fabricação, no Laboratório de Microbiologia do Setor de Laticínios, no Campus da USP em Pirassununga.

Para a produção do iogurte, foram acrescidas quantidades suficientes de cultivo starter (2\%) para cada volume de leite utilizado na iogurteira, seguido de homogeneização e incubação a $42^{\circ} \mathrm{C}$ por aproximadamente três horas, até alcançar o valor de $\mathrm{pH}$ de 4,5-4,65. Após este período, o produto foi resfriado até chegar a uma temperatura inferior a $20^{\circ} \mathrm{C}$, agitado manualmente com agitador de inox por cerca de 10 minutos (Figura 2) até a total homogeneização do coágulo e embalado manualmente em garrafas de polietileno com capacidade de $1.000 \mathrm{~mL}$.

A seqüência de fabricação descrita foi repetida cinco vezes, a cada 15 dias, no período de abril a junho de 2002, totalizando cinco lotes de iogurte para cada tratamento estabelecido no experimento. 


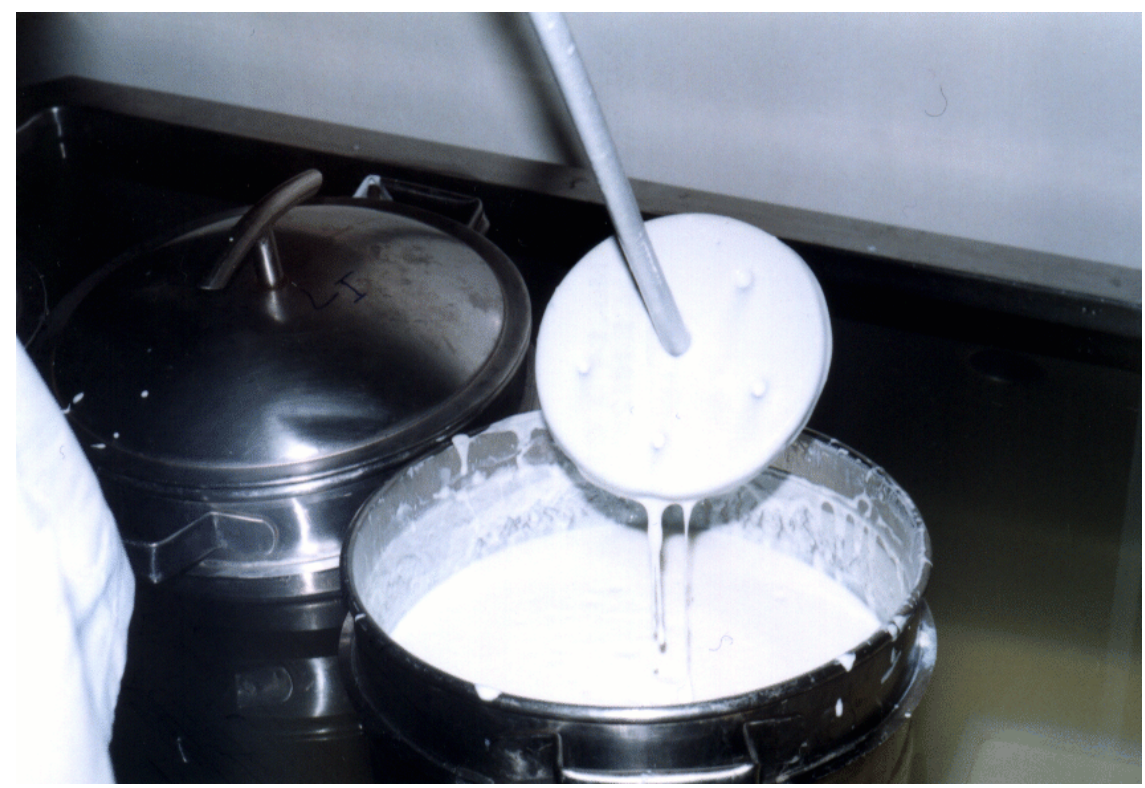

Figura 3. Aspecto do iogurte de leite desnatado de búfala (Tratamento C) após agitação do coágulo.

\section{5- Avaliação do logurte Natural Batido}

Os iogurtes processados foram armazenados em câmara fria à temperatura de $5^{\circ} \mathrm{C}$, por 30 dias. Foram colhidas duas amostras/lote do produto nos dias $1^{\circ}, 15^{\circ} \mathrm{e}$ $30^{\circ}$, para a execução das análises físico-químicas, reológicas e sensoriais. As análises microbiológicas foram efetuadas somente no dia um após a fabricação.

\subsection{1- Análises Microbiológicas}

No laboratório, as amostras foram previamente identificadas com data, número do lote e respectivo tratamento e submetidas imediatamente às análises microbiológicas preconizadas pela APHA (1992). A homogeneização das amostras foi efetuada na própria embalagem evitando-se a formação de bolhas de ar. A abertura das amostras foi realizada assepticamente com a retirada de alíquotas de um $\mathrm{mL}$, e em seguida transferidas para tubos de ensaio contendo água peptonada estéril. A partir desta diluição $\left(10^{-1}\right)$, foram realizadas as diluições subseqüentes (até $10^{-8}$ ), necessárias à análise de microorganismos mesófilos, psicrotróficos e coliformes.

A contagem de microorganismos mesófilos no iogurte foi realizada 
transferindo-se alíquotas de um $\mathrm{mL}$. das diluições obtidas para placas de Petri estéreis em duplicata, após o que foram adicionadas de Ágar Padrão para Contagem (PCA) e incubadas a $35^{\circ} \mathrm{C}$ por 48 horas. Para a contagem de psicrotróficos no iogurte, utilizouse este mesmo procedimento, porém foram transferidas alíquotas de 0,1 $\mathrm{mL}$ das diluições para placas em duplicata contendo o agar PCA solidificado (semeadura em superfície). O período de incubação foi de 7-10 dias em temperatura de $7^{\circ} \mathrm{C}$.

A determinação do NMP de coliformes totais do iogurte foi também realizada a partir das diluições obtidas com a água peptonada. Foram transferidas alíquotas de um $\mathrm{mL}$ para tubos de ensaio contendo tubos de Durhan invertidos, imersos em caldo lauril sulfato de sódio, os quais foram incubados a $35^{\circ} \mathrm{C}$ por $24 / 48$ horas. A determinação do NMP de coliformes fecais foi realizada a partir dos tubos positivos na análise de coliformes totais, utilizando-se o caldo verde brilhante - bile lactose (VBBL).

\subsection{2- Análises Físico-Químicas}

As análises físico-químicas nos iogurtes, abaixo discriminadas, foram realizadas de acordo com os procedimentos descritos pela AOAC (1995).

- $\mathrm{pH}$, determinado pela medida direta em $\mathrm{pH}$-metro digital, de marca Tecnal modelo Tec 2, introduzindo-se o eletrodo diretamente nas amostras;

- acidez, determinada por titulação com solução de $\mathrm{NaOH}$ 0,1 N, sendo expressa em g de ácido láctico/100 g do produto,;

- percentual de gordura, determinado pelo método de Gerber;

- percentual de proteína, determinado pelo método clássico de Kjeldahl (sistema micro);

- percentuais de EST, determinado através de método gravimétrico, e ESD, estimado pela diferença entre o EST e o teor de gordura; 


\subsection{3- Análise da Viscosidade Aparente}

O modelo utilizado na determinação da viscosidade aparente foi o Viscosímetro Digital Programável Brookfield (modelo DV-II+). Este era posicionado em local isolado de outros equipamentos e ligado com uma hora de antecedência da chegada das amostras. Este procedimento tinha por objetivo a estabilização do equipamento evitando-se a interferência de oscilações na corrente elétrica. O equipamento foi programado para permanecer registrando os valores em cP (Centipoise) durante um período de 20 minutos a 50 rpm (rotações por mínuto).

As amostras utilizadas na avaliação da viscosidade do iogurte foram transportadas em caixas de material isotérmico, contendo gelo reciclável suficiente para proporcionar à permanência da temperatura próxima a temperatura de armazenagem em câmara fria. Ao chegarem ao laboratório, às amostras permaneciam refrigeradas na caixa isotérmica até o momento em que cada garrafa tinha seu conteúdo homogenizado. Após esta etapa, cerca de $500 \mathrm{~mL}$ foram vertidos em um becker de $600 \mathrm{~mL}$, sendo registrados a temperatura inicial (média de $8,6^{\circ} \mathrm{C}$ ), os valores da viscosidade aparente e a temperatura final (média de $10,9^{\circ} \mathrm{C}$ ).

\subsection{4- Análises Sensoriais}

As amostras de iogurte foram submetidas a um painel não treinado (Amerine et al., 1967; IFT, 1981) constituídos por 85 provadores, recrutados entre alunos, professores e funcionários do Campus da USP em Pirassununga. Os testes foram conduzidos em instalação própria para a avaliação sensorial de alimentos, pertencente ao Campus, em cabines individuais nas quais os provadores atribuíram valores aos produtos numa escala hedonística de nove pontos para cada uma das seguintes características (Spreer, 1991): aspecto (peso 0,5); consistência (peso 1,0); odor (peso 0,5); e sabor (peso 2,0). O valor final de cada amostra correspondeu à média ponderada de pontos atribuídos pelos provadores para cada característica. As amostras foram submetidas ao painel em sua forma natural, sem acréscimo de outros 
ingredientes, à temperatura de cerca de $10^{\circ} \mathrm{C}$. O iogurte foi servido em copos de plástico incolor, em volumes de cerca de $70 \mathrm{ml}$.

A representação esquemática dos procedimentos experimentais, incluindo os pontos de amostragem e as análises laboratoriais, encontra-se na Figura 4.

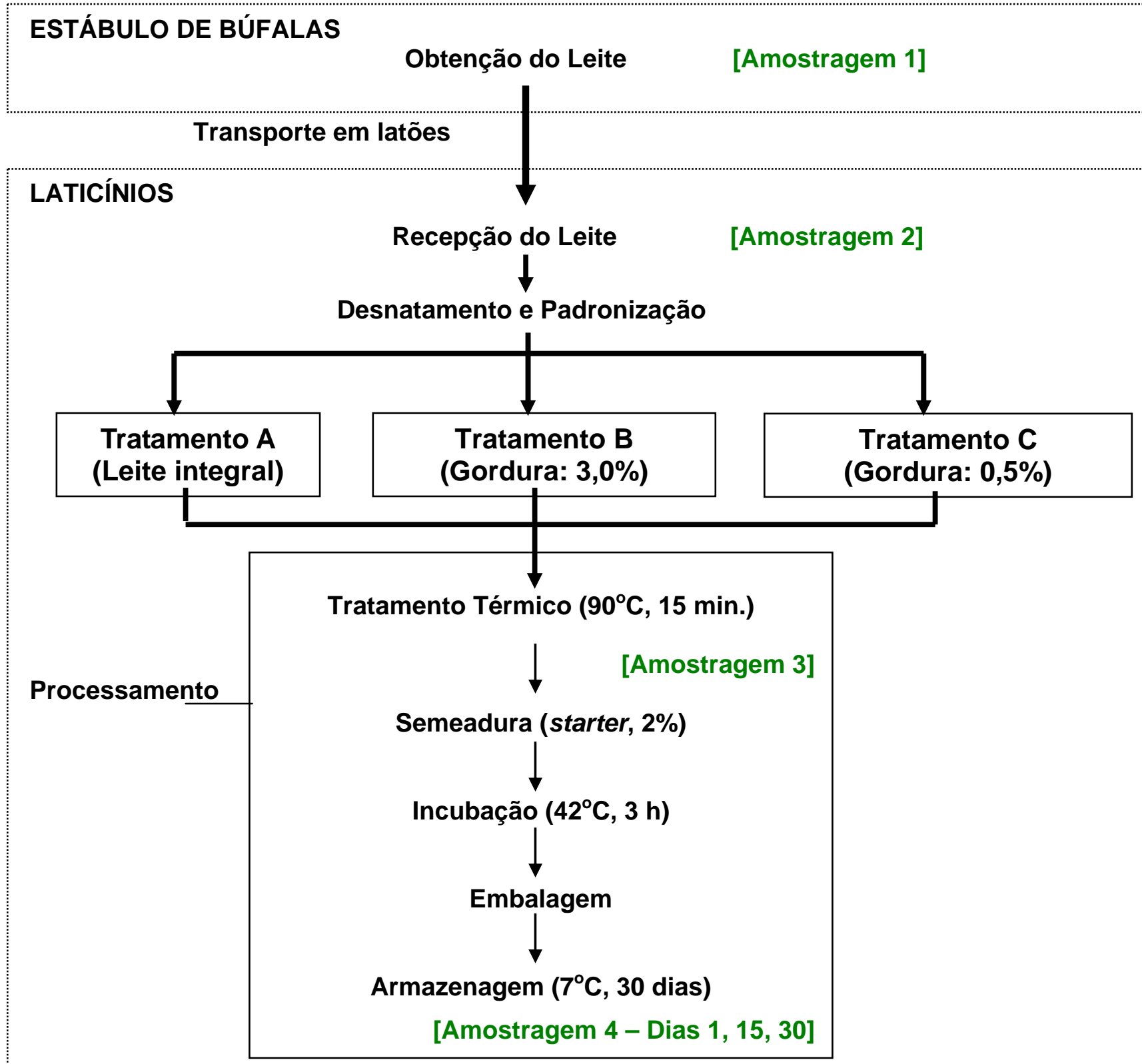

\section{Análises por pontos de amostragem:}

[1]- Mesófilos, psicrotróficos e coliformes (previamente ao início do experimento);

[2]- Densidade, pH, acidez, \% gordura, \% proteína, \%ES, \%ESD, mesófilos, psicrotróficos, coliformes;

[3]- Peroxidase, mesófilos, psicrotróficos, coliformes;

[4]- pH, acidez, \% gordura, \% proteína, \%ES, \%ESD, mesófilos, psicrotróficos, colif., viscosidade e aval. sensorial.

Figura 4. Fluxograma e resumo das atividades realizadas no experimento. 


\section{6- Análise Estatística}

Os resultados obtidos nos exames laboratoriais foram submetidos à análise de variância, considerando três tratamentos (iogurtes dos tipos integral, padronizado a $3,0 \%$ de gordura e desnatado a $0,5 \%$ de gordura) e cinco repetições a cada 15 dias. 0 delineamento experimental foi o de blocos casualizados. Para a comparação entre as médias empregou-se o teste de Tukey, adotando-se, como nível de rejeição, $\alpha=0,05$ (Gacula \& Singh, 1984).

Para o presente experimento serão considerados os seguintes conjuntos de hipóteses estatísticas:

- Para o fator tratamento

$$
\left\{\begin{array}{l}
\mathrm{H}_{0}: \mu_{\mathrm{i}}=\mu_{\mathrm{i}}, \text {, para qualquer } \mathrm{i} \neq \mathrm{i} \\
\mathrm{H}_{1}: \mu_{\mathrm{i}} \neq \mu_{\mathrm{i}}, \text {, para algum } \mathrm{i} \neq \mathrm{i}
\end{array}\right.
$$

- Para o fator bloco

$$
\left\{\begin{array}{l}
H_{0}: \mu_{j}=\mu_{j}, \text { para qualquer } \mathrm{j} \neq \mathrm{j}, \\
\mathrm{H}_{1}: \mu_{\mathrm{j}} \neq \mu_{\mathrm{j}}, \text { para algum } \mathrm{j} \neq \mathrm{j}
\end{array}\right.
$$

Assim, tem-se o seguinte modelo matemático:

$$
y_{i j k}=\mu+t_{i}+b_{j}+e_{i j k}
$$

$y_{\mathrm{ijk}}=\mathrm{k}$-ésima observação submetida ao i-ésimo nível do fator tratamento (tratamento térmico) e j-ésimo nível do fator bloco (dia de análise) $\mu=$ média geral

$\mathrm{t}_{\mathrm{i}}=$ efeito do i-ésimo nível do fator tratamento (tratamento térmico)

$b_{j}=$ efeito do j-ésimo nível do fator bloco (dia de análise)

$\mathrm{e}_{\mathrm{ijk}}=$ erro inerente a cada observação $\sim \operatorname{NID}\left(0, \mathrm{~s}^{2} \mathrm{e}\right)$

\section{4- RESULTADOS E DISCUSSÃO}

\section{1- Leite in natura}

A Tabela 1 apresenta os resultados obtidos nas análises físico-químicas e microbiológicas do leite in natura da espécie bubalina utilizado na fabricação dos iogurtes. Os valores físico-químicos apresentaram-se, de modo geral, dentro dos 
valores obtidos para o leite de búfala em todos os lotes por Verruma \& Salgado, (1994)

e Nader Filho et al. (1996), com pequenas variações.

Tabela 1. Parâmetros físico-químicos e microbiológicos do leite de búfala integral in natura.

\begin{tabular}{ccccccc}
\hline \multirow{2}{*}{ Parâmetros } & \multicolumn{7}{c}{ Lotes de Leite de Búfala } & \\
\cline { 2 - 6 } & $\mathbf{1}$ & $\mathbf{2}$ & $\mathbf{3}$ & $\mathbf{4}$ & $\mathbf{5}$ & Média $^{1}$ \\
\hline Índice Crioscópico $\left(-{ }^{\circ} \mathrm{C}\right)$ & 0,533 & 0,535 & 0,535 & 0,531 & 0,536 & $0,534 \pm 0,002$ \\
Densidade $\left(\mathrm{m} / \mathrm{v}, 15^{\circ} \mathrm{C}\right)$ & $1.032,6$ & $1.033,6$ & $1.034,0$ & $1.035,7$ & $1.033,3$ & $1.033,84 \pm 1,09$ \\
Acidez $\left({ }^{\circ} \mathrm{D}\right)$ & 20,0 & 20,5 & 19,0 & 20,0 & 21,0 & $20,10 \pm 0,99$ \\
PH & 6,79 & 6,67 & 6,75 & 6,60 & 6,70 & $6,70 \pm 0,07$ \\
Gordura (\%) & 6,85 & 7,00 & 6,75 & 6,80 & 6,70 & $6,82 \pm 0,11$ \\
Proteína (\%) & 4,34 & 4,60 & 4,08 & 4,10 & 4,30 & $4,28 \pm 0,20$ \\
EST $^{2}(\%)$ & 16,93 & 17,59 & 17,15 & 18,12 & 16,92 & $17,34 \pm 0,49$ \\
ESD $^{3}(\%)$ & 10,07 & 10,39 & 10,40 & 10,92 & 10,22 & $10,40 \pm 0,30$ \\
Mesófilos (Log UFC/ml) & 7,18 & 7,53 & 6,75 & 7,39 & 7,60 & $7,29 \pm 0,46$ \\
Psicrotróficos (Log UFC/ml) & 5,63 & 4,18 & 3,82 & 4,29 & 4,48 & $3,92 \pm 2,49$ \\
Coliformes Totais (Log NMP/ml) & 2,04 & 2,04 & 5,04 & 6,04 & 6,30 & $4,29 \pm 1,99$ \\
Coliformes Fecais (Log NMP/ml) & 2,04 & 2,04 & 0 & 0 & 0 & $0,82 \pm 1,05$ \\
\hline
\end{tabular}

${ }^{1}$ Resultados expressam a média \pm desvio padrão;

${ }^{2}$ EST: Extrato seco total; ${ }^{3}$ ESD: Extrato seco desengordurado.

Os valores médios encontrados para índice crioscópico $\left(-0,534^{\circ} \mathrm{C}\right)$, densidade $\left(1.033,84 \mathrm{~m} / \mathrm{v}, 15^{\circ} \mathrm{C}\right)$, acidez $\left(20,1^{\circ} \mathrm{D}\right)$ e $\mathrm{pH}(6,7)$ foram coerentes com os observados em estudos anteriores de Verruma \& Salgado (1994) e Nader Filho et al. (1996).

O percentual médio de gordura $(6,82 \%)$ foi semelhante aos valores encontrados por Furtado (1980b) e Nader Filho et al. (1996), porém, menor ao percentual de $8,16 \%$ descrito por Verruma \& Salgado (1994).

O teor de proteína $(4,28 \%)$ foi ligeiramente menor do que os resultados encontrados por Furtado (1980a) e Verruma \& Salgado (1994), de 4,79\% e 4,5\%, respectivamente.

Os percentuais médios obtidos para o EST e o ESD (17,34\% e 10,4\%) foram próximos dos resultados descritos por Furtado (1980b), porém, maiores aos valores encontrados por de $15,64 \%$ (EST) e $9,9 \%$ (ESD). 
Com relação aos resultados das análises microbiológicas, observou-se que a contagem média de mesófilos foi de 7,29 Log ufc/ml. Este valor foi maior do que o encontrado por lyengar et al. (1967) $\left(1,0 \times 10^{6} \mathrm{ufc} / \mathrm{mL}\right)$ em amostras de leite in natura, porém está dentro dos limites encontrados por Hofi et al. (1967) para o leite bubalino $\left(1,0 \times 10^{4}\right.$ a $\left.1,0 \times 10^{8} \mathrm{ufc} / \mathrm{mL}\right)$.

Segundo Farmisano et al. (1980) o manejo empregado durante o momento da ordenha é o principal fator que influencia a contaminação microbiana do leite. Assim, a utilização de algumas medidas higiênicas no momento da ordenha, como a lavagem da glândula mamária, o pré e pós-dipping (Fonseca \& Santos, 2001), devem ser rotineiramente empregadas nos rebanhos bubalinos para que a qualidade do produto final não seja influenciada pela contaminação inicial da matéria-prima.

O estudo dos níveis de contaminação por microorganismos do grupo dos psicrotróficos é necessário para que sejam conhecidas modificações no tempo de vida-de-prateleira (shelf-life) dos derivados lácteos, particularmente, em iogurte de leite bubalino, que permanecem armazenados em temperatura de refrigeração.

$\mathrm{Na}$ literatura não são encontradas referências sobre a ocorrência de microrganismos do grupo dos psicrotróficos em leite de búfala. Entretanto, os níveis de psicrotróficos obtidos leite bubalino in natura (3,92 Log $u f c / m L)$, no presente experimento, foram próximos dos valores reportados para o leite bovino. Deste modo, como a contagem destes microorganismos permaneceu baixa, pode-se considerar que não houve influências significativas sobre a qualidade dos iogurtes, uma vez que as alterações nas características sensoriais dos derivados lácteos são encontradas quando estão presentes contagens de psicrotróficos entre $10^{6} \mathrm{ufc} / \mathrm{ml}$ (Cousin, 1982) a $10^{7} \mathrm{ufc} / \mathrm{ml}$ (Shelley et al., 1987; Cromie, 1992).

Os níveis de coliformes totais variaram de 2,04 a 6,30 Log NMP/ml, sendo que coliformes fecais foram detectados apenas nos dois primeiros lotes, após o que foram novamente reforçados os procedimentos de higiene na ordenha. 


\section{2- Leite Pasteurizado:}

Os resultados da análise microbiológica do leite pasteurizado a $90^{\circ} \mathrm{C}, 15 \mathrm{~min}$., durante a fabricação do iogurte, encontram-se na Tabela 2. As contagens de microrganismos mesófilos e psicrotróficos foram drasticamente diminuídos em todos os tipos de leite, não havendo diferenças entre os mesmos $(P>0,05)$. Além disso, observou-se a completa destruição de coliformes totais, coliformes fecais e peroxidase, demonstrando que o tratamento térmico empregado foi eficiente na redução da carga microbiana inicial nos três leites.

Tabela 2. Parâmetros microbiológicos do leite de búfala pasteurizado ${ }^{1}$, de acordo com os tratamentos utilizados na fabricação do iogurte.

\begin{tabular}{cccccc}
\hline Tratamento & $\begin{array}{c}\text { Mesófilos } \\
\text { (Log ufc/ml) }\end{array}$ & $\begin{array}{c}\text { Psicrotróficos } \\
\text { (Log ufc/ml) }\end{array}$ & $\begin{array}{c}\text { Coliformes } \\
\text { Totais (NMP/ml) }\end{array}$ & $\begin{array}{c}\text { Coliformes } \\
\text { Fecais (NMP/ml) }\end{array}$ & Peroxidase \\
\hline Integral & $1,64 \pm 1,02$ & $0,75 \pm 0,87$ & 0 & 0 & Negativa \\
Padronizado & $1,73 \pm 0,73$ & $0,34 \pm 0,28$ & 0 & 0 & Negativa \\
Desnatado & $1,77 \pm 0,58$ & $0,22 \pm 0,30$ & 0 & 0 & Negativa \\
\hline
\end{tabular}

${ }^{1}$ NS: Não houve diferenças significativas entre os tratamentos utilizados $(P<0,05)$.

\section{3- logurte:}

\subsection{1- Características Microbiológicas:}

A Tabela 3 apresenta os resultados das análises microbiológicas do iogurte no dia 1 após a fabricação. Nesta ocasião, os níveis de mesófilos, psicrotróficos e coliformes foram muito semelhantes nos iogurtes elaborados com os diferentes tipos de leite $(P>0,05)$, comprovando que a elaboração dos iogurtes ocorreu de acordo com os procedimentos de boas praticas de fabricação. Ademais, todas as colônias obtidas nas placas de Petri incubadas a $37^{\circ} \mathrm{C}$ (mesófilos) apresentaram-se uniformes e com características típicas das bactérias do cultivo lácteo empregado na fabricação do iogurte.

As contagens de mesófilos variaram de 7,75 a 8,83 Log ufc/ml, o que parece compatível com o nível esperado de bactérias provenientes do cultivo lácteo e de 
acordo com os observados na literatura (International Dairy Federation, 1988).

Os níveis de psicrotróficos e coliformes totais foram bem menores, não sendo constatada a presença de coliformes fecais em nenhuma amostra de iogurte.

A presença do ácido lático no iogurte tem efeito preservativo e controla o crescimento da maioria dos microorganismos contaminantes (Robinson \& Tamime, 1993; Brandão, 1996). Segundo Ghani et al. (1998) coliformes presentes no iogurte recém-produzido em concentrações de $10^{2}-10^{5} \mathrm{NMP} / \mathrm{mL}$ foram completamente eliminados após um período de armazenamento de 15 dias.

Segundo Davis et al. (1971) citados por Brandão (1996), o nível de contaminação encontrado nos diferentes tratamentos indica que o iogurte apresenta nível satisfatório para os microorganismos testados.

Tabela 3. Parâmetros microbiológicos do iogurte ${ }^{1}$ no $1^{\circ}$ dia após a fabricação, de acordo com os tratamentos utilizados na fabricação do iogurte.

\begin{tabular}{ccccc}
\hline Tratamento & $\begin{array}{c}\text { Mesófilos (Log } \\
\text { ufc/ml) }\end{array}$ & $\begin{array}{c}\text { Psicrotróficos } \\
\text { (Log ufc/ml) }\end{array}$ & $\begin{array}{c}\text { Coliformes } \\
\text { Totais (NMP/ml) }\end{array}$ & $\begin{array}{c}\text { Coliformes } \\
\text { Fecais (NMP/ml) }\end{array}$ \\
\hline Integral & $8,83 \pm 0,81$ & $1,58 \pm 0,97$ & $0,07 \pm 0,16$ & 0 \\
Padronizado & $8,08 \pm 1,08$ & $0,71 \pm 0,97$ & $0,12 \pm 0,16$ & 0 \\
Desnatado & $7,75 \pm 1,09$ & $1,07 \pm 0,95$ & $0,50 \pm 0,83$ & 0 \\
\hline
\end{tabular}

${ }^{1}$ NS: Não houve diferenças significativas entre os tratamentos utilizados $(P<0,05)$.

\subsection{2- Características Físico-Químicas:}

A Tabela 4 apresenta os resultados das análises físico-químicas do iogurte nos dias 1, 15 e 30 após a fabricação, respectivamente. Para o dia 1 (Tabela 4), os valores de acidez, pH, proteína e ESD foram muito semelhantes nos iogurtes elaborados com os diferentes tipos de leite $(P>0,05)$. Os percentuais de gordura (Figura 6) e EST (Figura 8) variaram de acordo com a padronização, ou seja, os valores foram similares aos respectivos teores no leite utilizado como matéria prima. 
Tabela 4. Parâmetros físico-químicos do iogurte ${ }^{1}$ nos dias $1^{\circ}, 1^{\circ}$, e $30^{\circ}$ após a fabricação, de acordo com os tratamentos utilizados na fabricação do iogurte.

\begin{tabular}{ccccccc}
\hline Tratamento & Acidez (\%)2 & $\mathbf{p H}$ & Gordura (\%) & $\begin{array}{c}\text { Proteína } \\
\text { (\%) }\end{array}$ & EST $^{3}$ (\%) & ESD $^{4}(\%)$ \\
\hline Dia $1^{\circ}$ & & & & & & \\
Integral & $1,13 \pm 0,14^{*}$ & $4,41 \pm 0,23$ & $6,80 \pm 0,20^{\mathrm{a}}$ & $4,68 \pm 0,34$ & $16,40 \pm 0,32^{\mathrm{a}}$ & $9,60 \pm, 35$ \\
Padronizado & $1,17 \pm 0,22$ & $4,38 \pm 0,29$ & $3,12 \pm 0,27^{\mathrm{b}}$ & $4,65 \pm 0,27$ & $13,17 \pm 0,25^{\mathrm{b}}$ & $10,05 \pm 0,32$ \\
Desnatado & $1,12 \pm 0,15$ & $4,39 \pm 0,27$ & $0,50 \pm 0,10^{\mathrm{c}}$ & $4,17 \pm 0,16$ & $10,83 \pm 0,29^{\mathrm{c}}$ & $10,33 \pm 0,20$
\end{tabular}

Dia $15^{\circ}$

$\begin{array}{ccccccc}\text { Integral } & 1,17 \pm 0,07^{\star} & 4,20 \pm 0,14 & 6,80 \pm 0,32^{\mathrm{a}} & 4,44 \pm 0,23 & 16,40 \pm 0,26^{\mathrm{a}} & 9,60 \pm 0,27 \\ \text { Padronizado } & 1,22 \pm 0,02 & 4,18 \pm 0,09 & 2,94 \pm 0,22^{\mathrm{b}} & 4,54 \pm 0,15 & 13,07 \pm 0,47^{\mathrm{b}} & 10,13 \pm 0,49 \\ \text { Desnatado } & 1,21 \pm 0,07 & 4,12 \pm 0,08 & 0,48 \pm 0,08^{\mathrm{c}} & 4,74 \pm 0,78 & 10,81 \pm 0,35^{\mathrm{c}} & 10,33 \pm 0,29\end{array}$

Dia $30^{\circ}$

$\begin{array}{ccccccc}\text { Integral } & 1,23 \pm 0,22^{*} & 4,10 \pm 0,15 & 6,92 \pm 0,18^{\mathrm{a}} & 4,37 \pm 0,29 & 16,32 \pm 0,37^{\mathrm{a}} & 9,40 \pm 0,41 \\ \text { Padronizado } & 1,26 \pm 0,25 & 4,07 \pm 0,07 & 2,96 \pm 0,43^{\mathrm{b}} & 4,52 \pm 0,39 & 12,89 \pm 0,50^{\mathrm{b}} & 10,03 \pm 0,57 \\ \text { Desnatado } & 1,24 \pm 0,23 & 4,11 \pm 0,04 & 0,50 \pm 0,07^{\mathrm{c}} & 4,44 \pm 0,29 & 11,01 \pm 0,41^{\mathrm{c}} & 10,51 \pm 0,37\end{array}$

${ }^{1}$ Resultados expressam a média \pm desvio padrão de amostras (em duplicata) dos lotes 1 a 5.

${ }^{2} \%$ da ácido lático expressa em g de ácido láctico/100 g do produto; ${ }^{3} \mathrm{EST}$ : Extrato seco total; ${ }^{4}$ extrato seco desengordurado;

*Médias seguidas de letras desiguais diferem estatisticamente $(P<0,05)$ entre as linhas para os dias $1^{\circ}, 15^{\circ}$, e $30^{\circ}$.

Os resultados físico-químicos obtidos em todos os lotes de iogurte de leite de búfala estiveram de acordo com os parâmetros mínimos definidos na legislação brasileira para o produto conforme sua classificação em integral, padronizado e desnatado (Brasil, 1996).

Relativamente ao comportamento das variáveis ao longo do período de estocagem, observou-se que as diferenças nos parâmetros físico-químicos estudados 
continuaram semelhantes entre os iogurtes produzidos com os três tipos de leite, nas análises realizadas nos dias 15 e 30 após a fabricação. Neste período, a acidez aumentou em todos os produtos (Figura 5), ao passo que o $\mathrm{pH}$ diminuiu progressivamente durante o período de estocagem (Figura 5). Os resultados demonstraram que a padronização do teor de gordura não interferiu com estes parâmetros, os quais estão associados, principalmente, à atividade biológica do cultivo lácteo empregado na fabricação do iogurte (Spreer, 1991). Contudo, Chawla \& Balachandran (1994) observaram maior acidez e menores valores de pH à medida que o teor de ESD aumentou nos iogurtes de leite bubalino. No presente trabalho, não houve modificações significativas nos teores de ESD, proteína ao longo do período de armazenagem.

Os resultados encontrados para a acidez estão de acordo com os valores encontrados por Yabu et al. (1988) e Scholz \& Antunes (1996) utilizando leite integral de búfala na elaboração de iogurte $(0,78 \%$ e $1,21 \%$, respectivamente) e dentro do valor estabelecido pela legislação vigente $(0,6 \%$ a $1,5 \%)$, segundo a resolução $47 / 97$ (Mercosul, 2003). 


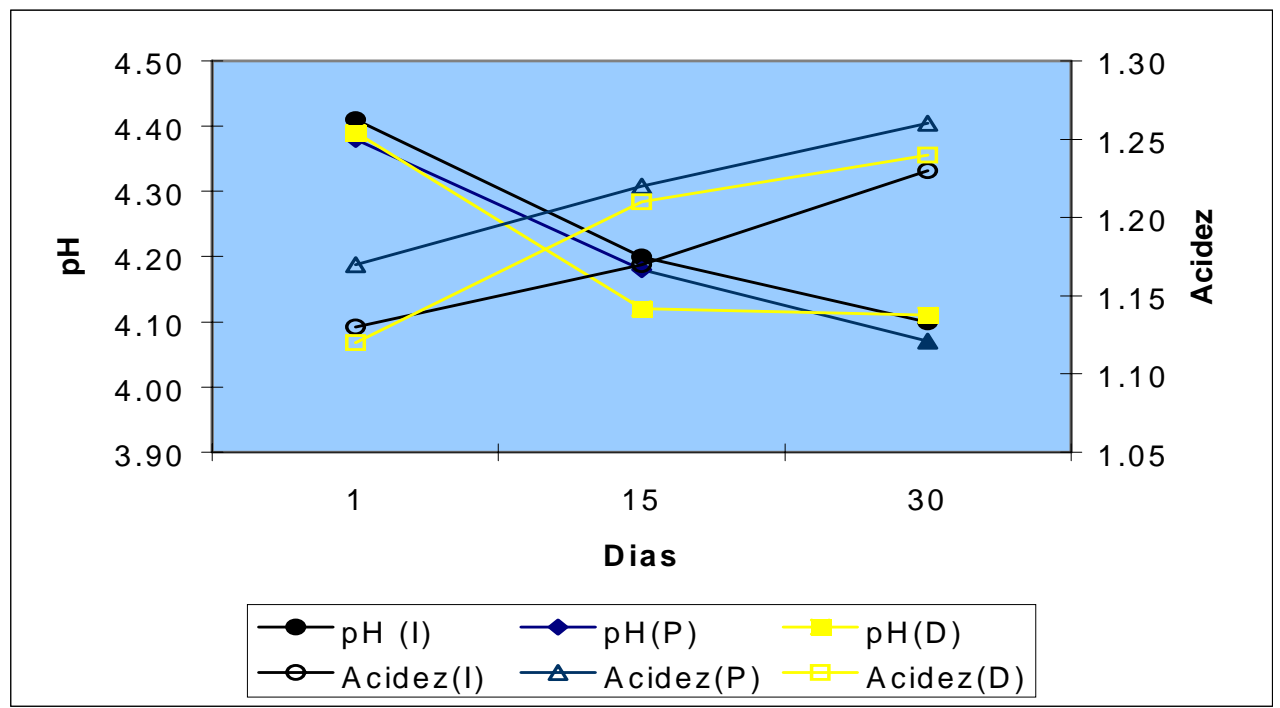

Figura 5. Evolução da acidez (expressa em \% de ácido lático/100 g do produto) e do $\mathrm{pH}$ dos iogurtes nos dias $1^{\circ}, 15^{\circ}$ e $30^{\circ}$ após a fabricação, de acordo com o tipo de tratamento utilizado.

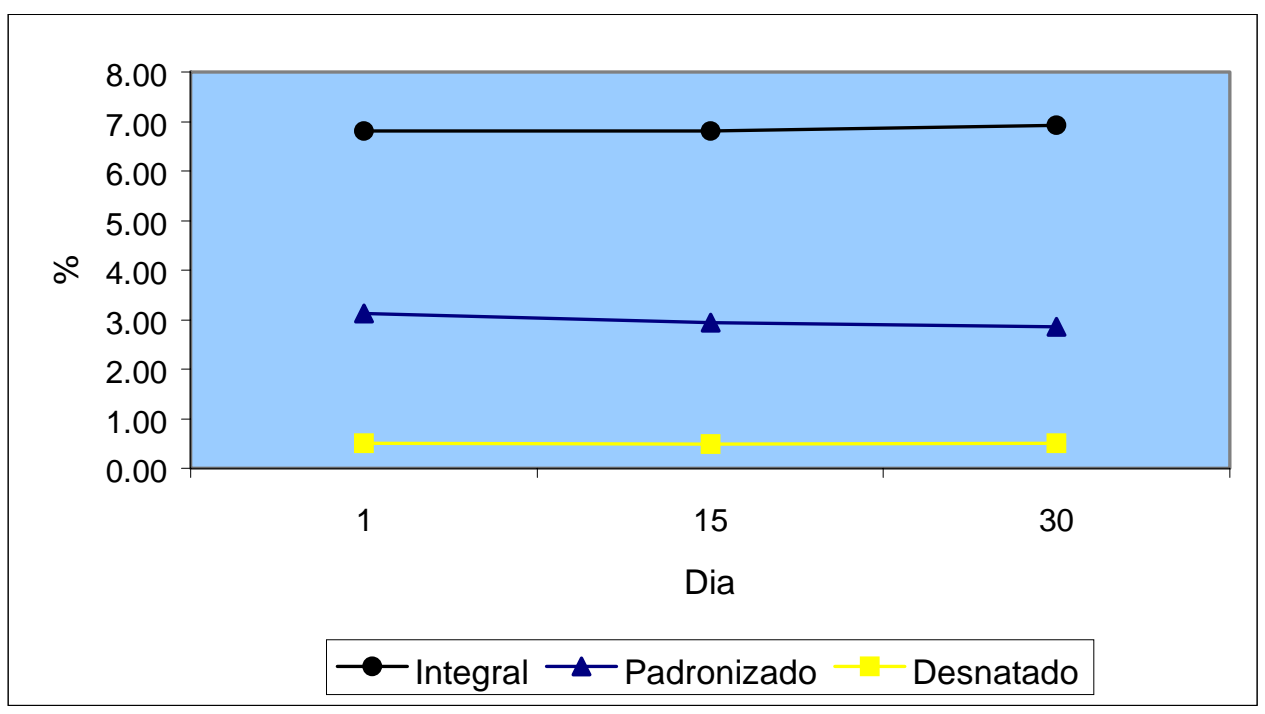

Figura 6. Evolução do teor de gordura (\%), dos iogurtes nos dias $1^{\circ}, 15^{\circ}$ e $30^{\circ}$ após a fabricação, de acordo com o tipo de leite utilizado em cada tratamento. 


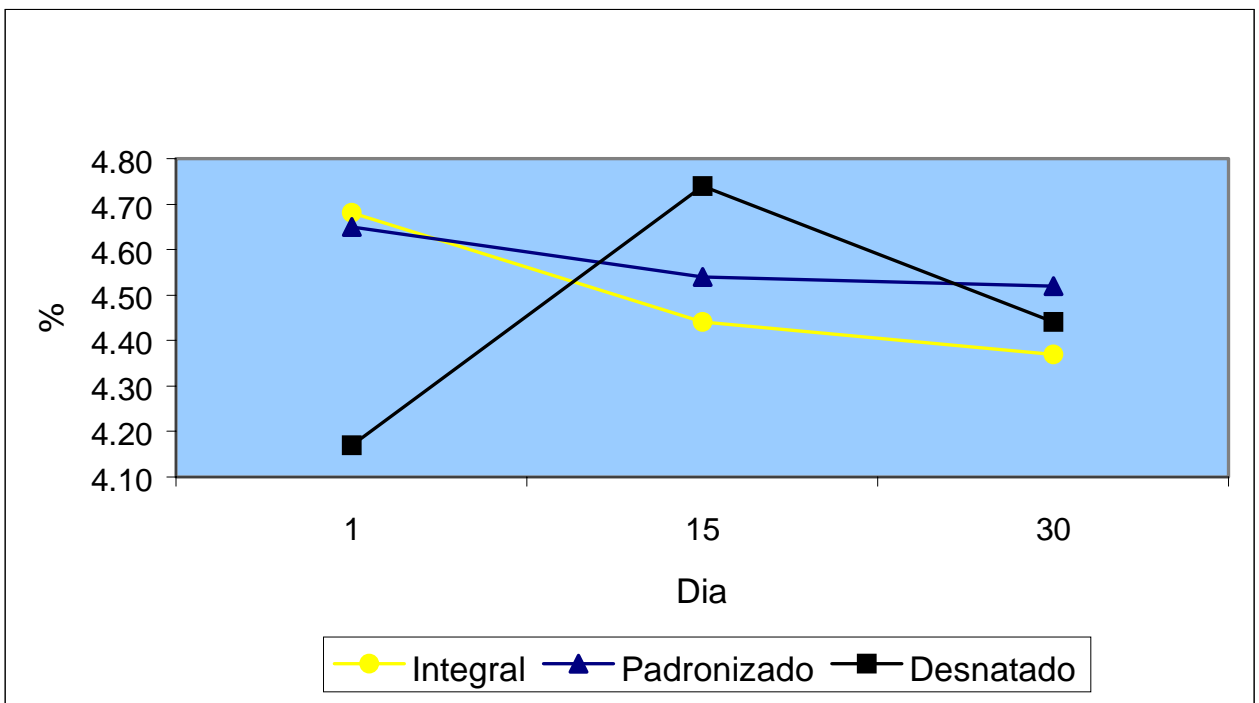

Figura 7. Evolução do teor de proteína (\%),dos iogurtes nos dias $1^{\circ}, 15^{\circ}$ e $30^{\circ}$ após a fabricação, de acordo com o tipo de leite utilizado em cada tratamento.

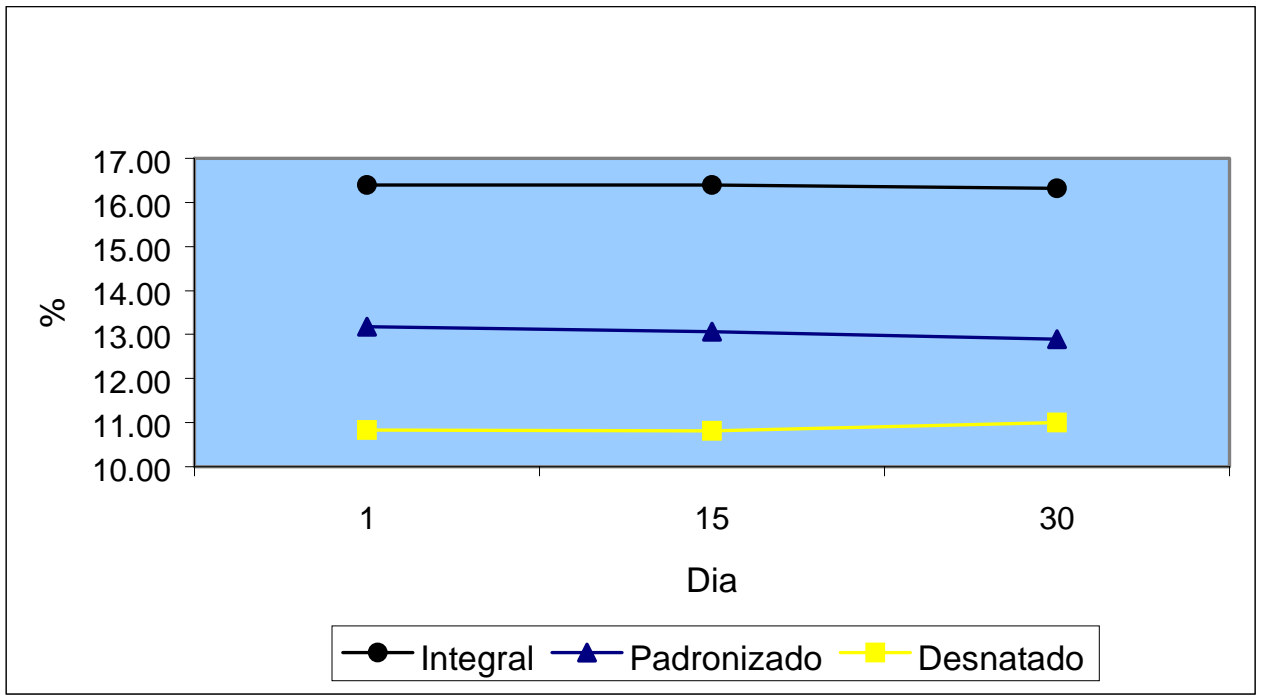

Figura 8. Evolução do EST (\%),dos iogurtes nos dias $1^{\circ}, 15^{\circ}$ e $30^{\circ}$ após a fabricação, de acordo com o tipo de leite utilizado em cada tratamento. 


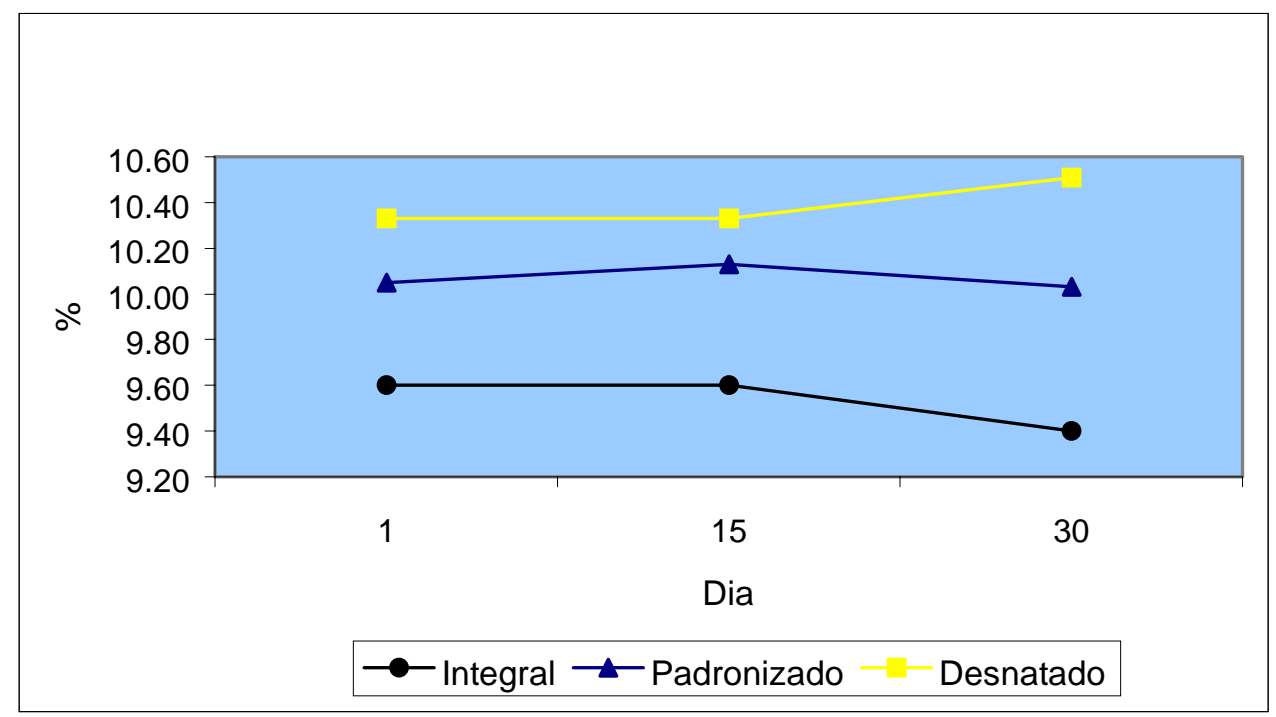

Figura 9. Evolução do ESD (\%),dos iogurtes nos dias $1^{\circ}, 15^{\circ}$ e $30^{\circ}$ após a fabricação, de acordo com o tipo de leite utilizado em cada tratamento.

\subsection{3- Viscosidade Aparente}

As curvas de viscosidade aparente (média de todos os lotes) dos tratamentos de iogurte utilizados encontram-se representados graficamente nas Figuras 10, 11 e 12, respectivamente, para os dias $1^{\circ}, 15^{\circ}$ e $30^{\circ}$ após a fabricação. Observou-se um aumento dos valores de viscosidade em todos os iogurtes, com pequenas variações entre cada tipo. Este fato está, possivelmente, relacionado à diminuição do pH observado ao longo do período de estocagem. No $1^{\circ}$ dia (Figura 10), o iogurte padronizado diferenciou-se dos demais tipos por apresentar valores de viscosidade ligeiramente menores. Inversamente, no $15^{\circ}$ dia (Figura 11), o iogurte padronizado apresentou maior viscosidade, seguido do desnatado e do integral. Ao $30^{\circ}$ dia (Figura 12), porém, os valores de viscosidade do iogurte natural foram maiores do que o padronizado, o qual apresentou viscosidade acima do iogurte desnatado. 


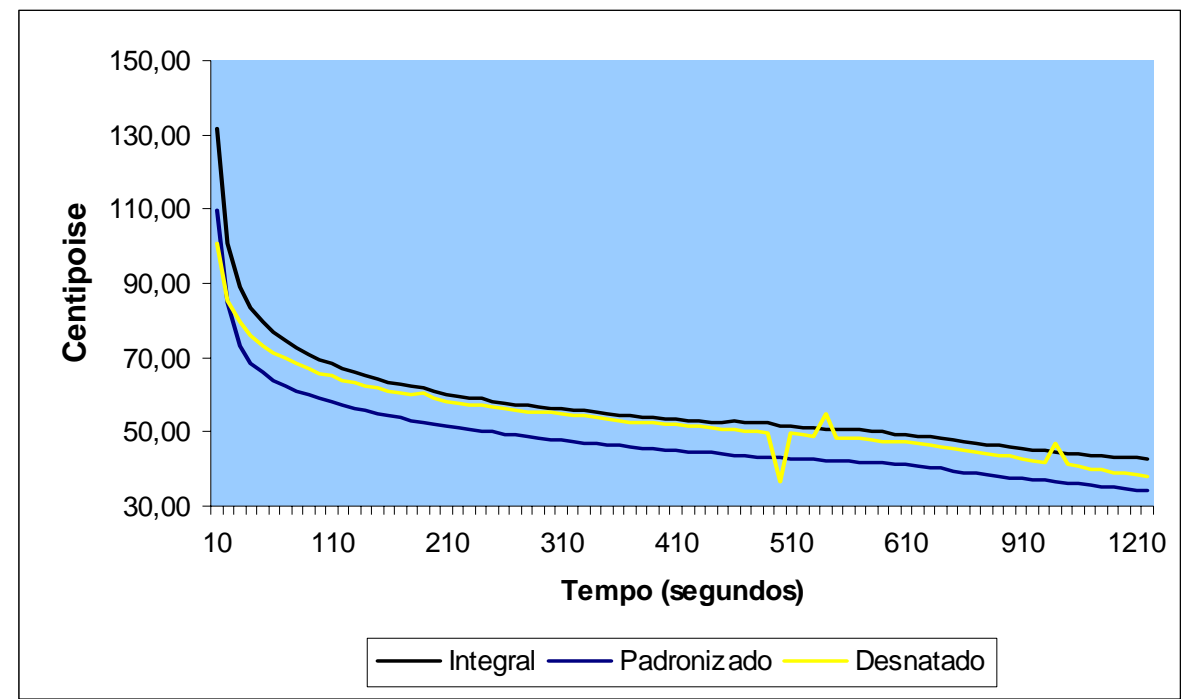

Figura 10. Viscosidade aparente (média, $\mathrm{n}=5$ ) do iogurte no $1^{\circ}$ dia de armazenamento.

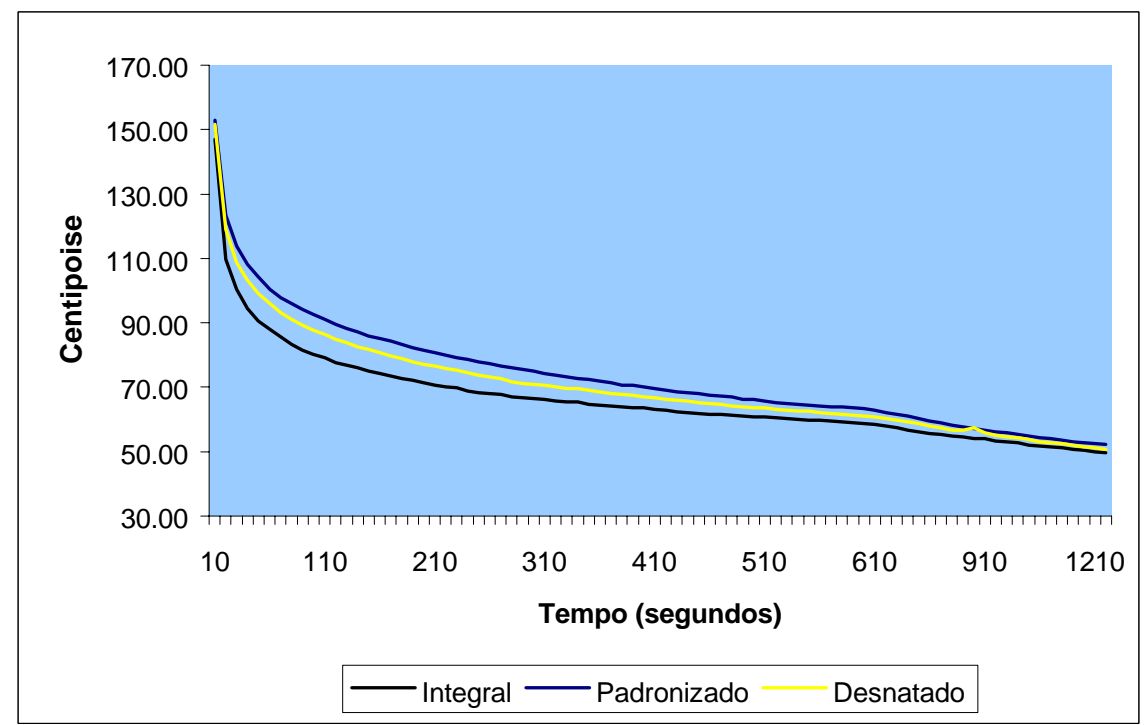

Figura 11. Viscosidade aparente (média, $\mathrm{n}=5$ ) do iogurte no $15^{\circ}$ dia de armazenamento. 


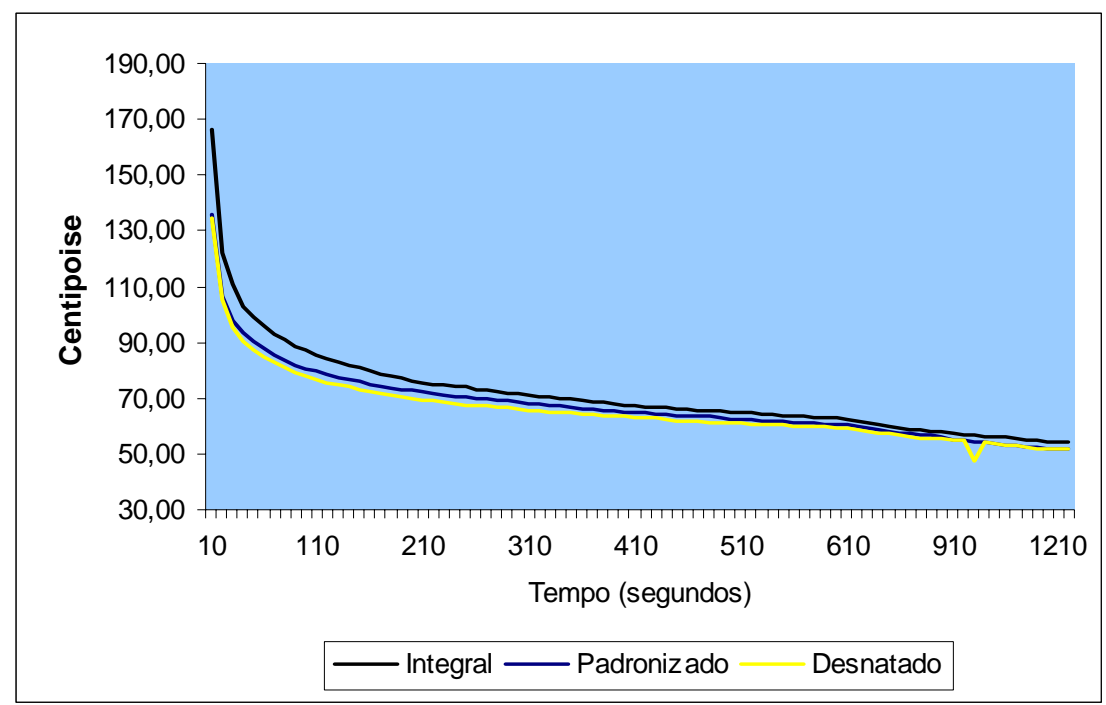

Figura 12. Viscosidade aparente (média, $\mathrm{n}=5$ ) do iogurte no $30^{\circ}$ dia de armazenamento.

As diferenças no comportamento das curvas de viscosidade, no entanto, não foram significativas $(P>0,05)$ (Tabela 5$)$, o que permite considerar que a redução do teor de gordura do leite de búfala não influenciou a viscosidade do iogurte natural, diferentemente do que ocorre no iogurte produzido com leite bovino (Spreer, 1991). Este fato indica que a adição de leite em pó ou outro método de reforço do teor de ESD no leite não é necessário para a manutenção das características físicas do iogurte produzido com leite desnatado de búfala.

Tabela 5. Viscosidade aparente do iogurte ${ }^{1}$ nos dias $1^{\circ}, 1^{\circ}$ e $30^{\circ}$ após a fabricação, de acordo com os tratamentos utilizados na fabricação do iogurte.

\begin{tabular}{cccc}
\hline \multirow{2}{*}{ Tratamento } & \multicolumn{2}{c}{ Viscosidade aparente (Centipoise - Cp) } \\
\cline { 2 - 4 } & Dia 1 & Dia 15 & Dia 30 \\
\hline Integral & $44,39 \pm 23,93^{\mathrm{a}^{*}}$ & $52,28 \pm 11,97^{\mathrm{a}}$ & $56,17 \pm 15,49^{\mathrm{a}}$ \\
Padronizado & $35,12 \pm 11,63^{\mathrm{a}}$ & $54,96 \pm 18,74^{\mathrm{a}}$ & $53,82 \pm 13,27^{\mathrm{a}}$ \\
Desnatado & $42,10 \pm 24,00^{\mathrm{a}}$ & $53,79 \pm 15,13^{\mathrm{a}}$ & $53,56 \pm 16,18^{\mathrm{a}}$ \\
\hline
\end{tabular}

${ }^{1}$ Resultados expressam a média \pm desvio padrão de amostras dos lotes 1 a 5 , considerando os valores do final do platô da curva de viscosidade (entre 820-1.240 s).

*Médias seguidas de letras desiguais diferem estatisticamente $(P<0,05)$ entre colunas. 


\subsection{4- Características Sensoriais}

A Tabela 6 apresenta os resultados obtidos na análise sensorial do iogurte nos dias 1, 15 e 30, respectivamente. Os atributos avaliados foram, conforme previsto, aspecto, consistência, odor, sabor e nota final de aceitação do produto. No $1^{\circ}$ dia de avaliação (Tabela 6), observou-se que todos os atributos avaliados apresentaram valores semelhantes nos três tipos de iogurte, com exceção da consistência do produto, cuja nota foi maior $(P<0,05)$ para o iogurte desnatado. Apesar disso, não houve diferenças significativas na nota final ponderada dos iogurtes. Além disso, não houve diferença $(P>0,05)$ nas notas atribuídas à consistência do iogurte nas avaliações dos dias 15 e 30, o que está em concordância com os resultados de viscosidade aparente obtidos para os três tipos de iogurte.

Nas avaliações dos dias 15 e 30 (Tabela 6), os valores atribuídos ao sabor dos iogurtes desnatado e integral foram menores ao do produto padronizado, embora a diferença tenha sido significativa $(P<0,05)$ somente com relação ao iogurte desnatado. Similarmente, as notas finais de aceitação do iogurte padronizado foram maiores do que os outros tipos, porém as diferenças não foram significativas.

As médias relativas ao aspecto e ao odor dos produtos não sofreram variações pronunciadas ao longo do período de estocagem, e também não apresentaram diferenças significativas $(P>0,05)$ nas avaliações, conforme pode ser observado nas Figuras 13, 14, 15, e 16. 
Tabela 6. Notas da análise sensorial do iogurte ${ }^{1}$ nos dias $1^{\circ}, 15^{\circ}$, e $30^{\circ}$ após a fabricação, de acordo com os tratamentos utilizados na fabricação do iogurte.

\begin{tabular}{cccccc}
\hline Tratamento & Aspecto & Consistência & Odor & Sabor & Nota Final $^{2}$ \\
\hline Dia $1^{\circ}$ & & & & & \\
Integral & $7,42 \pm 1,61 *$ & $7,12 \pm 1,64$ & $7,25 \pm 1,69$ & $6,54 \pm 1,98^{\mathrm{a}}$ & $6,88 \pm 1,64$ \\
Padronizado & $7,65 \pm 1,31$ & $7,44 \pm 1,31$ & $6,92 \pm 1,56$ & $6,36 \pm 1,88^{\mathrm{a}}$ & $6,86 \pm 1,33$ \\
Desnatado & $7,63 \pm 1,35$ & $7,56 \pm 1,14^{\mathrm{b}}$ & $7,01 \pm 1,45$ & $6,32 \pm 1,79^{\mathrm{a}}$ & $6,88 \pm 1,19$ \\
& & & & & \\
Dia 15 & & & & & \\
Integral & $7,67 \pm 1,21 *$ & $7,15 \pm 1,53$ & $7,10 \pm 1,61$ & $6,11 \pm 2,16^{\mathrm{ab}}$ & $6,69 \pm 1,53$ \\
Padronizado & $7,67 \pm 1,29$ & $7,00 \pm 1,74$ & $6,92 \pm 1,64$ & $6,42 \pm 1,87^{\mathrm{a}}$ & $6,78 \pm 1,33$ \\
Desnatado & $7,62 \pm 1,52$ & $7,03 \pm 1,56$ & $6,94 \pm 1,57$ & $5,63 \pm 2,11^{\mathrm{b}}$ & $6,39 \pm 1,50$ \\
& & & & & \\
Dia 30 & & & & & \\
Integral & $7,78 \pm 1,37 *$ & $7,07 \pm 1,73$ & $7,41 \pm 1,69$ & $5,52 \pm 2,03^{\mathrm{ab}}$ & $6,43 \pm 1,38$ \\
Padronizado & $7,74 \pm 1,06$ & $7,00 \pm 1,54$ & $6,93 \pm 1,41$ & $6,70 \pm 2,09^{\mathrm{a}}$ & $6,94 \pm 1,19$ \\
Desnatado & $7,70 \pm 1,35$ & $7,52 \pm 1,01$ & $7,26 \pm 1,38$ & $5,33 \pm 2,04^{\mathrm{b}}$ & $6,42 \pm 1,04$ \\
\hline
\end{tabular}

${ }^{1}$ Resultados expressam a média \pm desvio padrão;

${ }^{2}$ Nota final calculada com base na ponderação das notas individuais de cada atributo (aspecto e odor: peso 0,5 ; consistência: peso 1; sabor: peso 2).

*Médias seguidas de letras desiguais diferem estatisticamente $(P<0,05)$ entre as linhas para os dias $1^{\circ}, 15^{\circ}$, e $30^{\circ}$. 


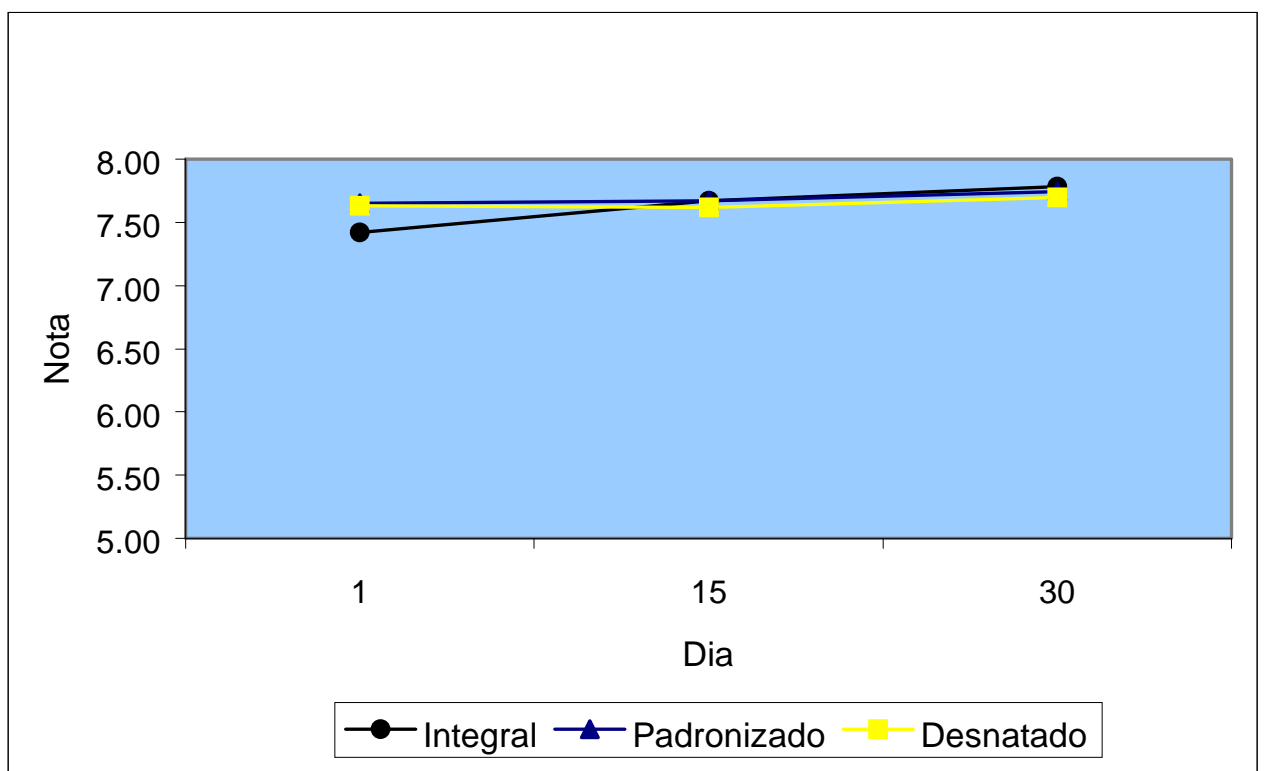

Figura 13. Evolução da nota média atribuída ao aspecto do iogurte durante 30 dias de armazenamento.

A Figura 17 demonstra a evolução das notas finais de aceitação ao longo do período de 30 dias de estocagem. Em síntese, pode-se afirmar que todos os iogurtes produzidos no experimento foram adequados ao consumo. Contudo, o iogurte produzido com leite padronizado apresentou maior estabilidade do que os demais tipos, uma vez que as notas de aceitação mantiveram-se relativamente constantes após 15 e 30 dias em câmara a $5^{\circ} \mathrm{C}$. Deve-se ressaltar, também, que esta preferência dos avaliadores, ligeiramente maior para o produto padronizado (gordura $=3,0 \%$ ), pode ser devida, entre outros fatores, à similaridade da composição deste com o iogurte integral batido elaborado com leite bovino. 


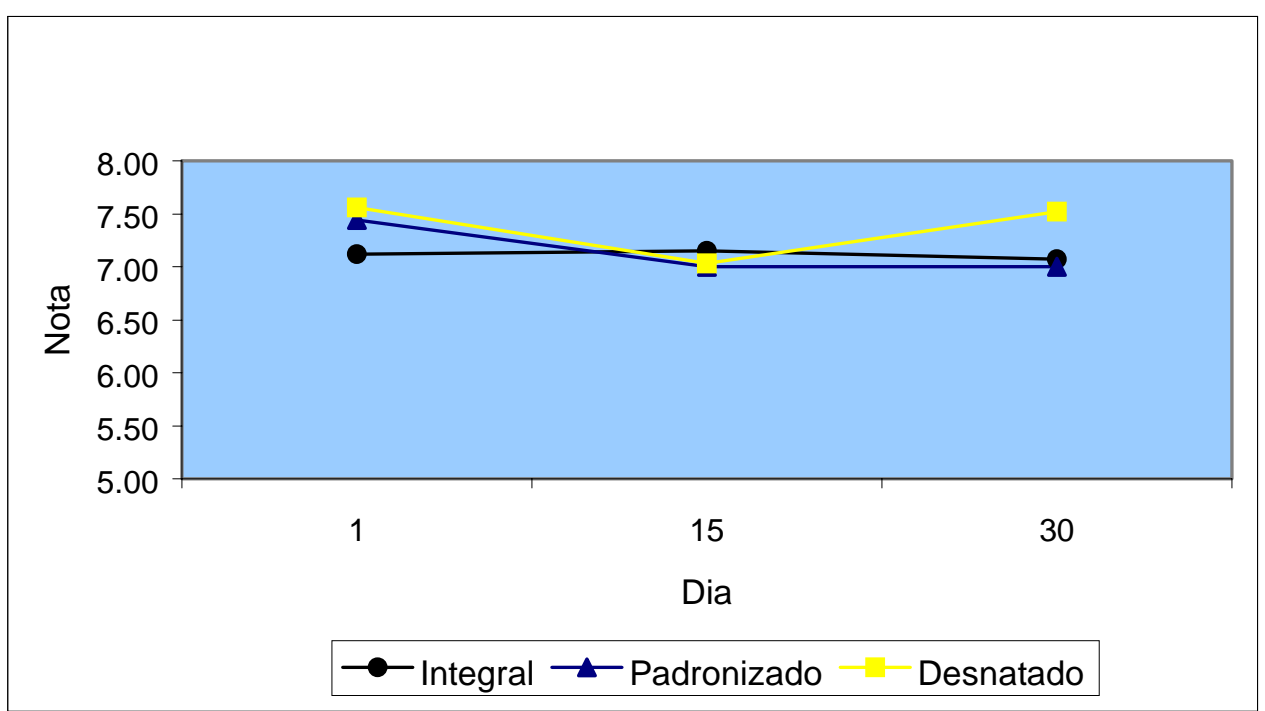

Figura 14. Evolução da nota média atribuída à consistência do iogurte durante 30 dias de armazenamento.

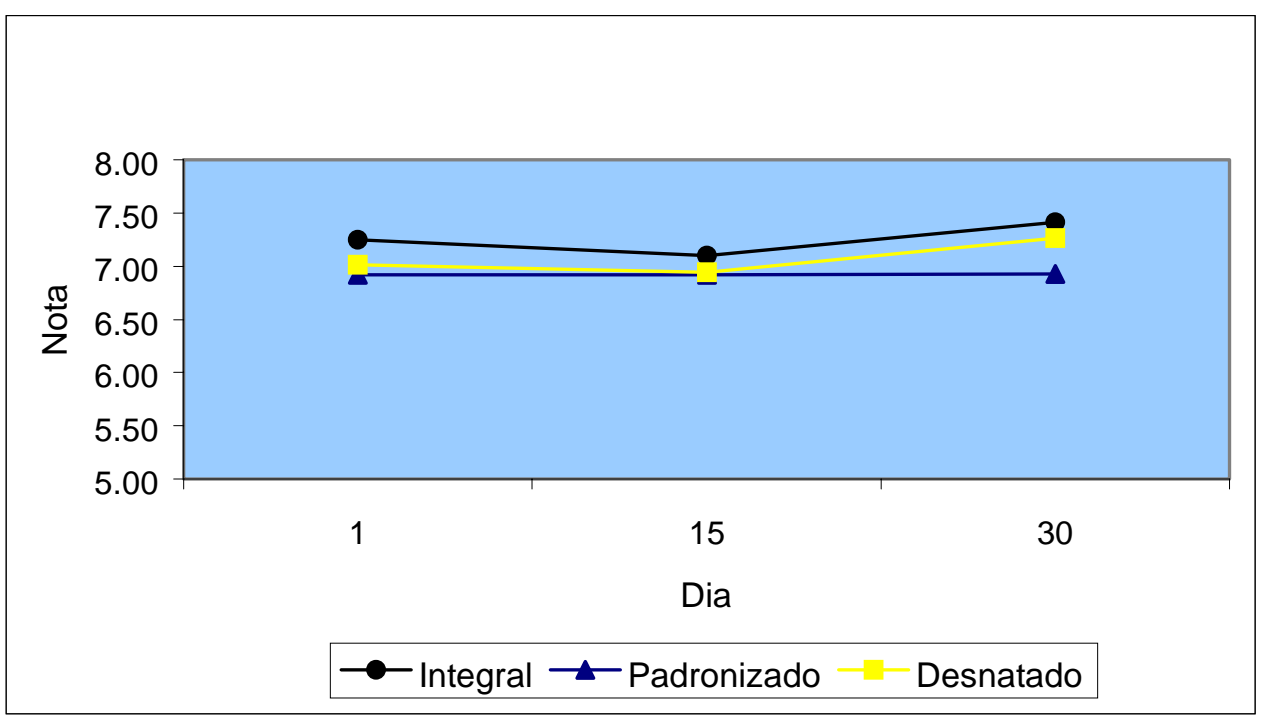

Figura 15. Evolução da nota média atribuída ao odor do iogurte durante 30 dias de armazenamento.

O leite bubalino por apresentar valores maiores para os seus sólidos totais (ESD, gordura, minerais, proteína, e vitaminas) confere características peculiares aos derivados lácteos, o que permite a obtenção de produtos, como o iogurte, com propriedades diferentes das observadas do iogurte elaborado com o leite da espécie bovina. Na literatura mundial, porém, os parâmetros de qualidade no iogurte produzido exclusivamente com o leite de búfala são pouco estudados. As características que mais prevalecem nos trabalhos são as físico-químicas e as microbiológicas, sendo as 
propriedades sensoriais e as possíveis alterações do produto durante o período de vida-de-prateleira as menos estudadas. No único trabalho disponível, Chawla \& Balachandran (1994) observaram que o iogurte de leite de búfala contendo 3,0\% de gordura e 10\% de ESD apresentou notas de avaliação sensorial próxima ao do iogurte padronizado do presente experimento, cuja composição também foi próxima.

A avaliação sensorial realizada no presente experimento demonstrou que 0 iogurte produzido exclusivamente com leite de búfala apresenta um bom potencial de mercado em nossas condições.

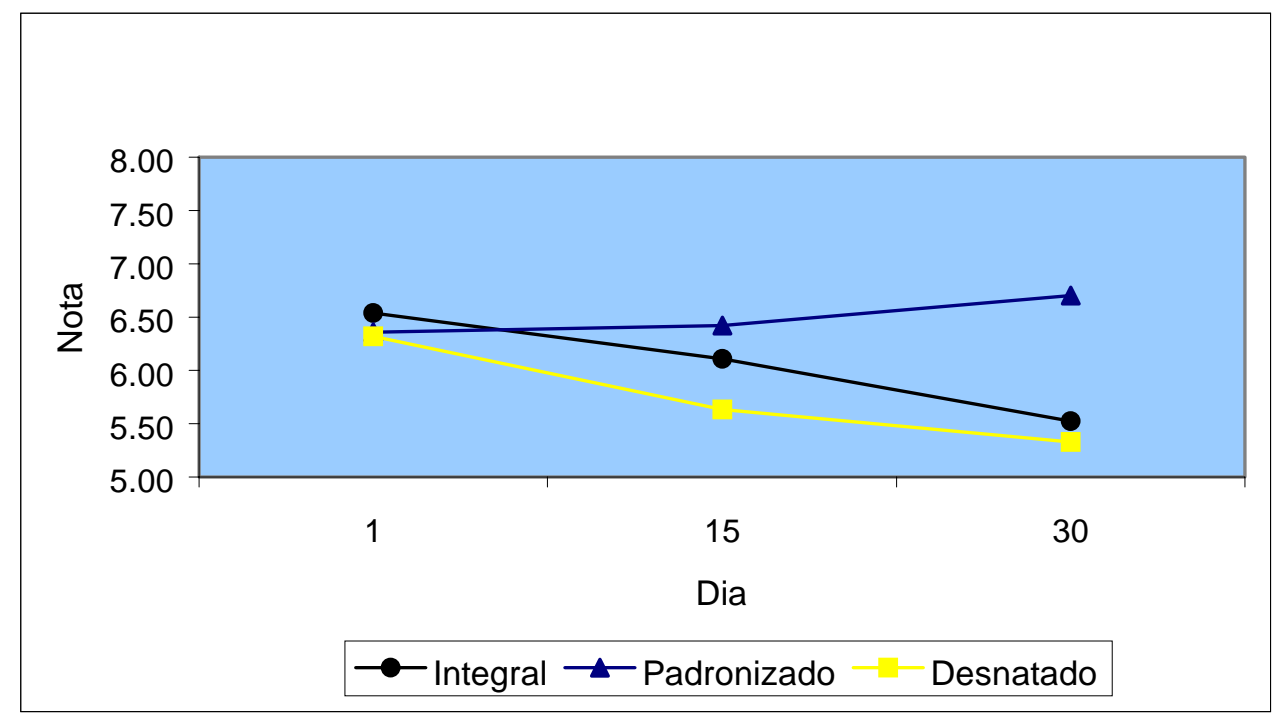

Figura 16. Evolução da nota média atribuída ao sabor do iogurte durante 30 dias de armazenamento. 


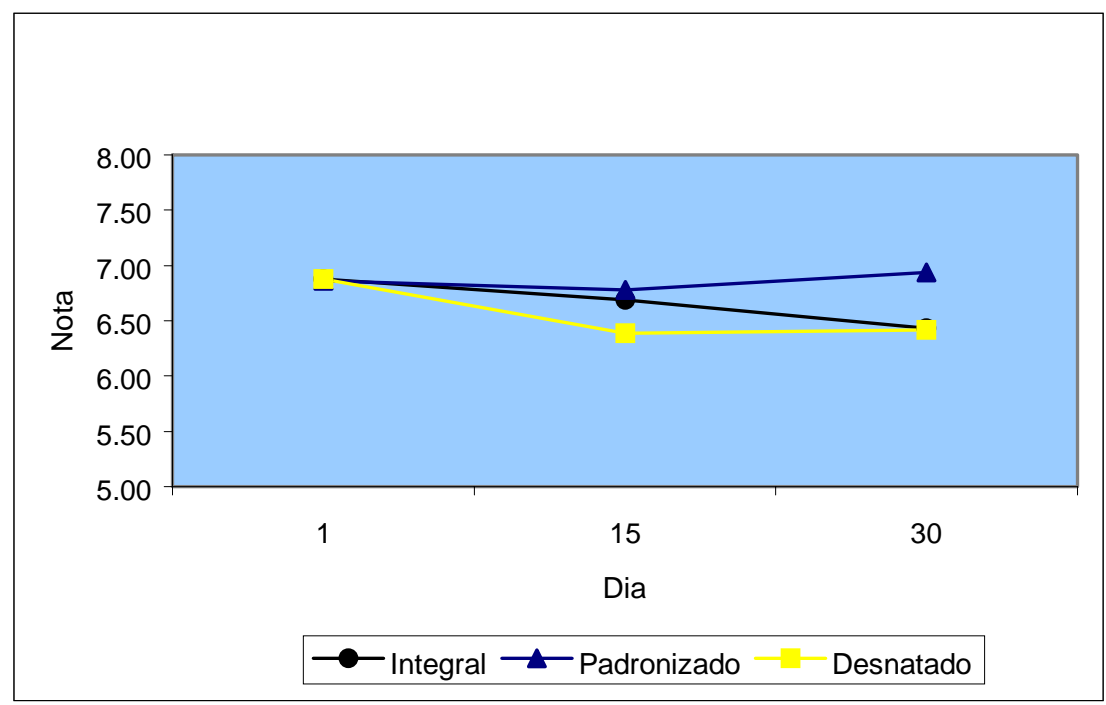

Figura 17. Evolução da nota final de avaliação sensorial do iogurte durante 30 dias de armazenamento. 


\section{5- CONCLUSÕES}

Face aos resultados obtidos no presente experimento, e considerando os objetivos propostos, pode-se concluir que:

a- Os iogurtes produzidos com leite bubalino integral, padronizado e desnatado apresenta características microbiológicas e percentuais de proteína e ESD semelhantes, mantendo-se com poucas alterações durante 30 dias de armazenamento;

b- Os valores de viscosidade aparente dos iogurtes padronizado e desnatado não mostraram diferenças com o produto integral, o que dispensa a prática de fortalecimento do ESD do leite de búfala submetido ao desnatamento parcial ou total;

c- O iogurte produzido com leite padronizado a 3,0\% de gordura apresenta melhor aceitação quanto ao sabor somente em relação ao iogurte desnatado;

d- Os atributos aspecto, consistência e odor dos iogurtes não variaram ao longo do período de armazenagem;

e- O iogurte de leite de búfala, principalmente o produto contendo $3,0 \%$ de gordura, apresenta boa estabilidade ao longo do período de armazenamento (30 dias);

f- O leite de búfala integral, padronizado ou desnatado parcial ou totalmente é adequado para a manutenção das características físicas do iogurte produzido, não necessitando fortalecimento adicional. 


\section{6- REFERÊNCIAS BIBLIOGRÁFICAS}

AMERICAN PUBLIC HEALTH ASSOCIATION. Standard methods for the examination of dairy products. 16th ed. Washington, APHA, 1992.

AKBAR, M.A.; KULDIP; KUMARI, R.; SINGH, N. Effect of feeding by pass protein with and without biopromotors on milk production, and certain rumen and blood metabolites in lactating Murrah buffaloes. Indian Journal of Animal Science, v. 69, n. 11, p. 967971, 1999.

AMERINE, M.A.; PANGBORN, R.M.; ROESSLER, E.M. A principle of sensory evaluation of foods. New York, Academic Press, 1967.

ANTUNES, L.A.F.; YABU, M.C.; SCHOLZ, M.B.S.; RAPACCI, M. Variações físicoquímicas e sensoriais em misturas de leites bovino e bubalino. Revista do Instituto de Lacticínios Cândido Tostes, v. 43, n. 259, p. 20-22, 1988.

ANUÁRIO MILKBIZZ. Anuário Milkbizz 1999/2000. São Paulo: Ed. Milkbizz, 1999.

ANUALPEC 2002. São Paulo: FNP, 2002.

AOAC. Official Methods of analysis of AOAC International. 16th. ed. Washington: Association of Official Analytical Chemists, 1995.

BENEZECH, T.; MAINGONNAT, J.F. Characterization of rheological properties of yogurt. A review. Journal Food Engineering, London, v. 21, n. 4, p. 447-472, 1994.

BESHKOVA, D.; SIMOVA, E.; FRENGOVA, G.; SIMOV, Z. Production of flavour compounds by yogurt starter cultures. Journal of Microbiology \& Biotechnology, v. 20, p. 180-186, 1998.

BOBBIO, P.A.; BOBBIO, F.O. Química do processamento de alimentos. 3. ed. São Paulo: Livraria Varela, 2001.

BRANDÃO, S.C.C. Tecnologia da produção industrial de leite. Revista Leite e Derivados, n. 25, p. 24-38, 1995. 
BRANDÃO, S.C.C. Controle da qualidade na produção industrial de iogurte. Revista Leite e Derivados, n. 28, p. 63-67, maio/jun., 1996.

BRASIL. Ministério da Agricultura, Abastecimento e da Reforma Agrária. Portaria $\mathrm{n}^{\circ}$ 146/96. Aprova os Regulamentos Técnicos de Identidade e Qualidade dos Produtos Lácteos. Diário Oficial da União, Brasília, 07 mar. 1996.

BRASIL. Ministério da Agricultura, Métodos analíticos oficiais para o controle de produtos de origem animal e seus ingredientes. Brasília, Métodos físico-químicos, 1981.

BURKI, C.; BLANC, B. International Dairy Congress, 20. p. 287, 1978.

CHAWLA, A.K.; BALACHANDRAN, R. Studies on yoghurt buffalo milk: effect on different solids not fat content on chemical, rheological and sensory characteristics. Indian Journal Dairy Science, v. 47, n. 9, p. 762-765, 1994.

COUSIN, M.A. Presence and activity of psychrotrophic microorganisms in milk and dairy oriducts: a review. Journal Food Protection, n. 45, p. 172-207, 1982.

CROMIE, S. Psychrotrophs and their enzyme residues in cheese milk. Australian Journal Dairy Technology, n. 47, p. 46-100, 1992.

DASTUR, N N.; LAXMINARAYMA, H. Buffaloes milk and milk products. Dairy Science Abstracts, Wallingford, v. 30, n. 4, p. 177-186, 1968.

DUBEY, P.C; SUMAN, C.L.; SANYAL, M.K.; PANDEY, H.S.; SAXENA, M.M.; YADAV, P. L. Factors affecting composition of milk of buffaloes. Indian Journal of Animal Sciences, v. 67, n. 9, p. 802-804, 1997.

DURAN, L.; COSTELL, E. Revisión. Percepción del gusto. Aspecto fisicoquímicos y psicofísicos. Food Science Technology International. v. 5, n. 4, p. 299-309, 1999.

ELFGAM, A.A.; WHEELOCK, J.V. Journal Dairy Science. v. 61, p. 159, 1978b. 
FARMISANO, M.; PERCUOCO,G.; PERCUOCU,S. Qualitative and quantitative distribuition of microflora in buffaloes's milk related to season and milking method. Dairy Science Abstracts. v. 42, p. 6663, 1980.

FERRARA, B.; INTRIERI, F. Características e emprego do leite de búfala. Zootecnia, São Paulo, v. 13, n. 1, p. 25-50, jan./mar., 1975.

FERREIRA, V.L.P.; ALMEIDA, T.C.A.; PETTINELLI, M.L.C.; SILVA, M.A.A.P.; CHAVES, J.B.P.; BARBOSA, E.M.M. Análise sensorial: testes discriminativos e afetivos. Manual: série qualidade. São Paulo: SBCT, 2000. 127 p.

FONSECA, L.F.L.; SANTOS, M.V. Qualidade do leite e controle de mastite. São Paulo: Lemos Ed., 2000.

FONSECA, M.G D; MORAIS, E.M. Industria de leite e derivados no Brasil: uma década de transformações. Informações Econômicas, v. 29, n. 9, p. 7-29, 1999.

FOOD AND AGRICULTURE ORGANIZATION. O Búfalo: produção animal e saúde. São Paulo: Associação Brasileira dos Criadores de Búfalos, 1991.

FOOD AND AGRICULTURE ORGANIZATION. FAOSTAT: Agriculture data. Disponível em: http://apps.fao.org/cgi-bin/nph-db.pl?subset=agriculture Acesso em: 1999.

FOOD AND AGRICULTURE ORGANIZATION. Disponível em: <http://apps.fao.org/cgibin/nph-db.pl?subset=agriculture.html>. Acesso em: 20 mar. 2003.

FRANCISCIS, G.; DI PALO, R. Buffalo milk production. In: WORLD BUFFALO CONGRESS, 4., 1994, São Paulo. Proceedings... São Paulo: WBC, 1994. v. 1, p. 137147.

FURTADO, M.M. Composição centesimal do leite de búfala, na zona da mata mineira. Revista do Instituto de Lacticínios "Cândido Tostes", Juiz de Fora, v. 35, n. 211, p. 4347, 1980a.

FURTADO, M.M. Leite de búfala: Estudo da fabricação do queijo azul. Revista do Instituto de Laticínios Cândido Tostes, Juiz de Fora, p.23-31, 1980b. 
GACULA, J.R.; SINGH, J. Statistical methods in food and consumer research. Orlando: Academic Press, 1984.

GANGULI, N.C. Buffalo milk technology. Revista Mundial de Zootecnia, v. 30, p. 2-10, 1979.

GHANI, S.A.; SADEK, Z.; FATHI, F. Reliability of coliform bacteria as an indicator of postprocessing contamination in yogurt manufacture. Dairy, Food and Environment Sanitation. v. 18, n. 7, p. 494-498, aug., 1998.

HOFI, A.A.; RAMADAN, F.M.; FODA, E.A. Studies on market raw buffalos'milk. II. Bacteriological quality with special reference to dye tests. Ann. Agr. Sci. Uni. A' in Shams v. 10, n. 2, p. 127-157, 1967.

HÜHN, S.; GUIMARÃES, M.C.; NASCIMENTO, C.N.B.; MOURA CARVALHO, L.O.B.; MOREIRA, E.D.; LOURENÇO JÚNIOR, J.B. Estudo comparativo da oposição química do leite de zebuínos e bubalinos, Belém: EMBRAPA_CPATU, 1982. (Boletim de Pesquisa, 36).

INSTITUTO ADOLFO LUTZ. Normas Analíticas do Instituto Adolfo Lutz. 3. ed. São Paulo: IAL, 1985. v.1.

INTERNATIONAL DAIRY FEDERATION. Yogurt enumeration of characteristic microorganisms. Colony count technique at $37^{\circ} \mathrm{C}$. International IDF Standard, n. 146 , 1988.

INSTITUT OF FOOD TECHNOLOGISTS. Sensory evaluation guide for testing food and everage products. Food Technology, v. 35, n. 11, p. 50-59, 1981.

IYENGAR, M.K.K.; NAMBUDRIPAD, V.K.N; DUDANI, A.T. Effect of heat-treatment of buffalo and cow milk in the manufacture of yoghurt. Indian Journal of Dairy Science, v. 20, p. 8-10, 1967.

KIM, B.Y.; KINSELLA, J.E. Rheological changes during slow acid induced gelation of milk by D-glucona- $\delta$-lactone. Journal Food Science, n. 54, p. 894-898, 1989.

LEWIS, M.J. Physical properties of dairy products. In: ROBINSON, R. K. Modern Dairy Technology. Cap. 5, v. 2, 1994. 516 p. 
LEWIS, M.J.; DALE, R.H. Chilled yogurt and other dairy desserts. Shelf- Life Evaluation of Foods, 2. ed., p. 126-155, 1996.

MERCOSUL/GMC/Res. N 47/97 Regulamento técnico Mercosul de identidade e qualidade do leite fermentado. Disponível em: <http://www.mercosur.org.uy/portugues/snor/normativa/resoluciones/1997/47-97.htm>. Acesso em: 14 mar. 2003.

MOCQUOT, G.; HUREL, C. The seletion and use of some micro-organisms for the manufacture of fermented and acidified milk products. Journal of the Society of Dairy Technology, v. 23, n. 3, 130-142, 1970.

MOREIRA, S.R.;SCHWAN, R.F.; CARVALHO, C.F. Análise microbiológica e química em iogurtes comercializados em Lavras, MG. Ciência e Tecnologia de Alimentos, v. 19, n. 1, p. 147-152, 1999.

NADER FILHO, A.; AMARAL, L. A.; TONHATI, H.; PENHA, L.H.C.; TOLEDO, L.M. Variação das características físico-químicas do leite de búfala, durante os diferentes meses do período de lactação. Artigos de Veterinária, v. 12, n. 2, p. 148-153, 1996.

NADER FILHO, A.; SCHOCKEN-ITURRINO, R.P.S.; ROSSI JÚNIOR, O.D.; FILHO, M. Estudo da determinação do ponto crioscópico do leite de búfala. Revista do Instituto de Laticínio Cândido Tostes, v. 38, n. 228, p. 21-23, 1983.

NADER FILHO, A.; SCHOCKEN-ITURRINO, R.P.S.; ROSSI JÚNIOR, O.D; FILHO, M. Influência do teor de proteínas totais na acidez titulável e pH do leite de búfala. Revista do Instituto de Laticínio Cândido Tostes, v. 39, n. 231, p. 25-28, 1984.

NADER FILHO, A.; SCHOCKEN-ITURRINO, R.P.S.; ROSSI JÚNIOR, O.D.; EÇA, F.A. D. Características físico-químicas do leite bovino, bubalino e do produto da mistura do leite de ambas as espécies. Artigos de Veterinária, v. 2, n. 1, p. 95-106, 1986.

NASCIMENTO, C.; CARVALHO, C.O.M. Criação de búfalos. Brasília: EMBRAPA, 1993. 
NEVES, N.L.B. Contribuição da bubalinocultura para a produção leiteira. In: PEIXOTO, A.M.; MOURA, J.C.; FARIA, V.P. Caracterização e implantação de uma política para o leite. Piracicaba: FEALQ, 1985. p. 37-46.

OLIVEIRA, C.A.F.; FONSECA, L.F.L.; GERMANO, P.M.L. Aspectos relacionados à produção, que influenciam a qualidade do leite. Higiene Alimentar, v. 13, p. 10-16, 1999.

QUEIROZ, L.S.O.; LOURENÇO JÚNIOR, J.B.; Souza, C. Avaliação microbioógica de iogurte de leite de búfala, com sabor de frutas da Amazônia, para a merenda escolar. Higiene Alimentar, v. 16, n. 94, p. 39-44, 2002.

ROBINSON, R.K.; TAMIME, A.Y. Manufacture of yogurt and other fermented milks. In: Robinson, R. K. (Ed.) Modern dairy technology. 2. ed. London: Chapman \& Hall, 1993. p. 1-47.

SANTOS, E.S.; CARVALHO, E.P.; ABREU, L.R. Psicrotróficos: consequências de sua presença em leites e queijos. Boletim da Sociedade Brasileira para a Ciência e Tecnologia de Alimentos, v. 33, n. 2, p. 129-138, jul./dez., 1999.

SANTOS, M.V.; FONSECA, L.F.L. Importância e efeito de bactérias psicrotróficas sobre a qualidade do leite. Higiene Alimentar, v. 15, n. 82, p. 13-19, 2001.

SHAKER, R.R.; JUMAH, R.Y.; ABU-JDAYIL. Rheological properties of plain yogurt during coagulation process: impact of fat content and preheat of milk. Journal of Food Engineering, n. 44, p. 175-180, 2000.

SHEATA, A.E.; MAGDOUB, M.N.I.; SULTAN, N.E; EL-SAMRAGY, Y.A. Aerobic mesophilic and psychrotrophic sporeforming bacteria in buffalo milk. Journal of Dairy Science, v. 66, p. 1228-1231, 1982.

SHELLEY, A.W.; DEETH, H.C.; MACRAE, I.C.A numerical taxanomic study of psycrotrophic bacteria asscociad with lipolytic spoliage of raw milk. Journal of Apllied Bacteriology, v. 62, n. 3, p. 197-207, 1987.

SCHOLZ, M.B.; ANTUNES, L.A.F. Aproveitamento da mistura de leite de vaca e de búfala para a produção de iogurte. I. Aspectos Físico-químicos e microbiológicos. Revista do Instituto de Laticínios Cândido Tostes, v. 50, n. 297, p. 30-46, jan./jun., 1996. 
SØRHAUG, T.; STEPANIAK, L. Psychrotrops and heir enzymes in milk and dairy products: quality aspects. Trends in Food Science \& Technology, february, v. 8, n. 2, feb. 1997.

SOUZA, G. logurte: Tecnologia, consumo e alta produção. Leite e Derivados, n. 28, maio, 1996.

SPREER, E. Lactologia industrial. 2. ed. Zaragoza: Acribia, 1991.

TAMIME, A.Y.; DEETH, H.C. Yogurt: Technology and biochemistry. Journal of food protection, v. 43, n. 12, p. 939-977, dec., 1980.

TAMIME, A.Y.; ROBINSON, R.K. Yoghurt sciences and techology. Oxford: Pergamon Press, 1985. $341 \mathrm{p}$.

VAN DENDER, A.G.F.; MOERNO, I.; GARCIA, S. Uso de creme de leite de búfala e de vaca na fabricação do queijo tipo mascarpone. Revista do Instituto de Laticínios Cândido Tostes, v. 43, n. 259, p. 35-42, 1988.

VARNAM, A.; SUTHERLAND, J.P. Leche y productos lácteos: tecnología, química e microbiología. Zaragoza: Editora Acribia, 1994. p. 476.

VERRUMA, M.R.; SALGADO, J.M. Avaliação nutricional do leite de búfala em comparação ao leite de vaca. Scientia Agrícola, v. 51, n. 1, p. 131-137, 1994.

VERRUMA, M.R.; OLIVEIRA, A.J. Avaliação química e nutricional do queijo mozzarella e iogurte de leite de búfala. Scientia Agrícola, v. 50, n. 5, p. 438-443, 1993.

VIEIRA, S.D.A.; NEVES, B.S. Padronização do teor de gordura e do extrato seco desengordurado do leite de búfala com leite reconstituído. Revista do Instituto de Laticínios Cândido Tostes, v.35, n.208, p.27-33, 1980.

YABU, M.C.; SCHOLZ, M.B.S.; RAPACCI, M.; ANTUNES, L.A.F. Características físico-químicas e sensoriais de iogurte produzido de misturas de leite bovino e bubalino. Revista do Instituto de Laticínios Cândido Tostes, v. 43, n. 258, p. 35-37, 1988. 